\title{
The Smiling Abbot: Rediscovering a Unique Medieval Effigial Slab
}

\author{
Howard Williams, Gillian Smith, David Crane and Aaron Watson \\ Williams, H., Smith, G., Crane, D. and Watson, A. (2017): The Smiling Abbot: Rediscovering \\ a Unique Medieval Effigial Slab, Archaeological Journal. DOI: \\ 10.1080/00665983.2017.13366705
}

\begin{abstract}
The article reports on a newly re-discovered fragment of a recumbent effigial slab commemorating Abbot Hywel ('Howel'), most likely an abbot of the Cistercian house of Valle Crucis, near Llangollen (Denbighs.). The slab was probably carved very early in the fourteenth century, and could have covered the abbot's burial place. The stone was dislocated and fragmented at an unknown point in the abbey's history, and most likely removed from the site during the nineteenth-century clearance of the abbey ruins. It was briefly reported on in 1895 and has been lost to scholarship subsequently.

If indeed from Valle Crucis, the stone is the only known effigial slab commemorating a Cistercian abbot from Wales, and a rare example from Britain. Given that few similar Cistercian abbatial monuments have been identified from elsewhere, the 'Smiling Abbot', although only a fragment, is a significant addition to the known corpus of later medieval mortuary monuments. The article discusses the provenance, dating, identification and significance of the monument, including the abbot's distinctive smile. The stone sheds new light on mortuary and commemorative practice at Valle Crucis Abbey in the early fourteenth century.
\end{abstract}

\section{Introduction}

A medieval carved stone, hitherto only briefly reported on by Stephen Williams $(1895,124-$ 25), resurfaced by being brought to the attention of Llangollen Museum in early 2016. Supported by high-resolution digital photography, this article provides a first detailed description and interpretation of the effigial slab's provenance, date, and proposes the identification of its subject as a Cistercian abbot of Valle Crucis (Illus 1-3). Having established its authenticity, the study then explores the wider significance of the monument for appreciating Valle Crucis Abbey as a centre of memorial stone-carving and mortuary commemoration in the early fourteenth century. The article also considers the implications of the stone's re-discovery for understanding medieval Cistercian abbatial mortuary commemoration more broadly.

\section{Background}

The stone was reported by S. Williams $(1895,124-5)$ accompanied by a crude illustration (Illus. 1) as being 'brought from Caer Gai (near Bala Lake/Llyn Tegid) and 'now at Wynnstay'. No subsequent mention was made of this stone in scholarly literature. It was acquired by Meryl and Jerry Butler at an auction of building stone at Lindisfarne College, Wynnstay Hall, near Chirk, in the 1980s. By this time it was already a fragment and 
separated from the remainder of the slab: the owners have no recollection of the rest of the slab being in the auction.

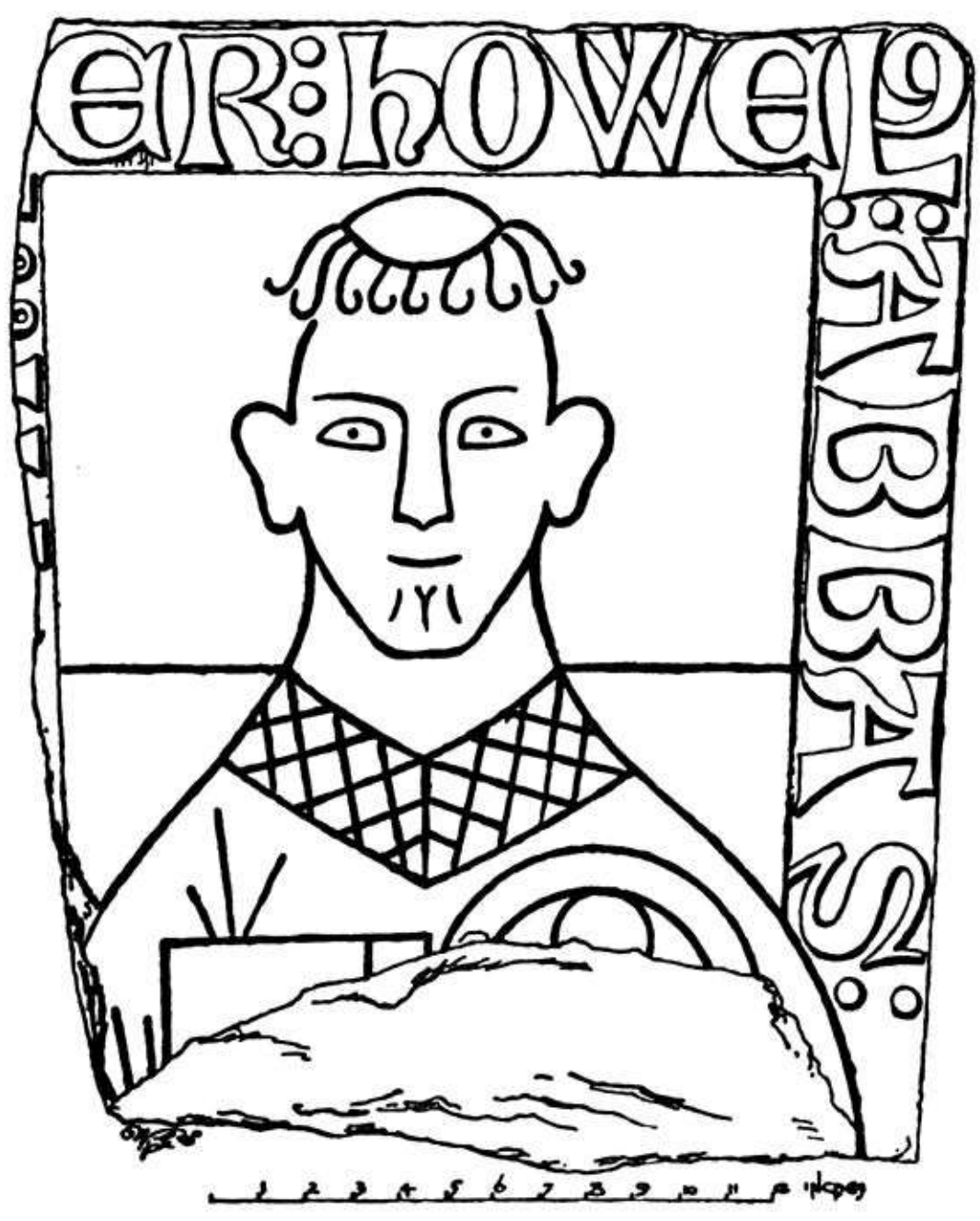

\section{No. 7.-Fragment of Sepulchral Slab from Caer Gai, now at Wynnstay. Scale, one-eighth actual size.}

Illus. 1 The original illustration of the 'Smiling Abbot' (after S. Williams 1895, 124). Notable features no longer clear on the stone include (a) the bases of letters running up the left-hand side, two dots after the ' $S$ ', a vertical line bisecting the rectangle (book) on the figure's right chest and the semicircle within the double-lined arc on the figure's left side (paten)

The Butlers subsequently displayed the monument in their private home and subsequently on their business premises. They had previously attempted to alert specialists as to its possible significance having conducted their own initial research.

In March 2016, the carved stone was brought to the attention of Gillian Smith of Llangollen Museum, and in liaison with David Crane, also of Llangollen Museum, a temporary loan of the slab fragment was negotiated. The monument has been on display at Llangollen Museum from that time until early 2018 , after which time its fate is uncertain. 


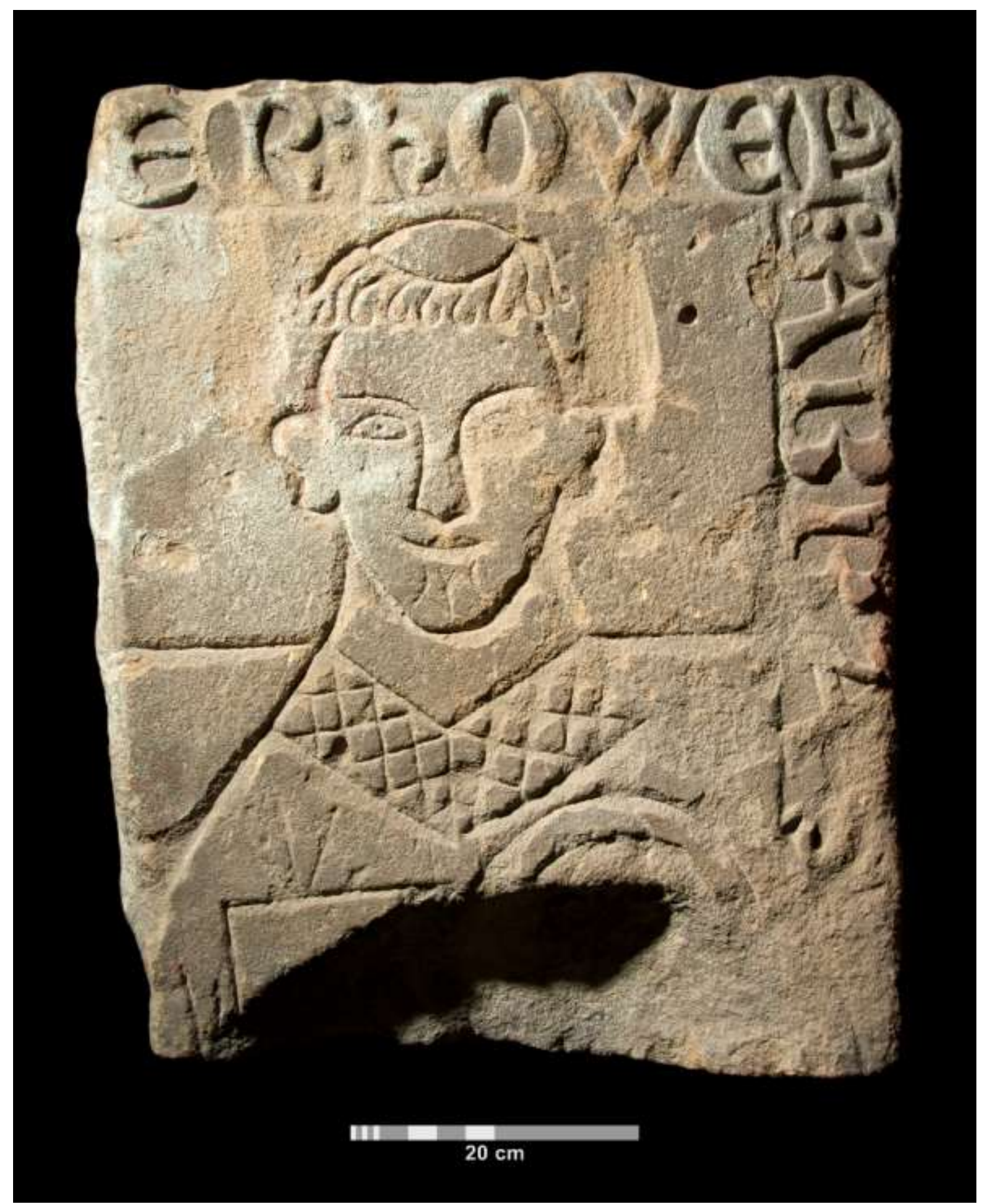

Illus. 2 The effigial slab, currently on display at Llangollen Museum, lit from top-left. (Photograph: Aaron Watson, 2017) 


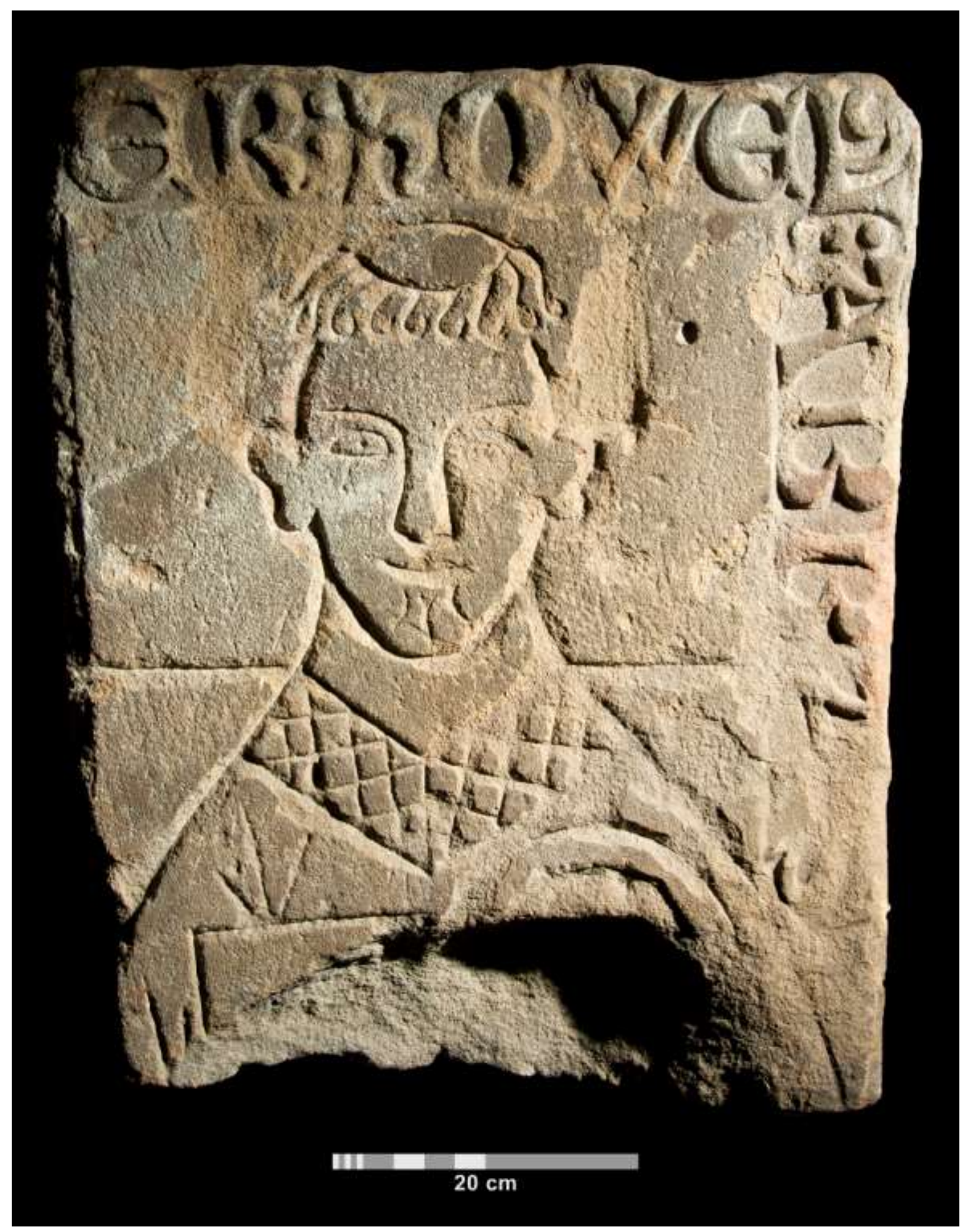

Illus. 3 The effigial slab, currently on display at Llangollen Museum, lit from top-right. (Photograph: Aaron Watson, 2017) 


\section{Description}

Form, Material, and Alteration

The carved stone fragment is the head-end of a recumbent grave-slab (Illus 2 and 3). The maximum surviving stone dimensions measure $620 \mathrm{~mm}$ in length, $520 \mathrm{~mm}$ in breadth, and $140 \mathrm{~mm}$ deep. The original long-side is angled inwards, indicating that this is part of a trapezoidal grave-slab. The text is in relief and the figure is deeply and crudely incised: a distinctive feature of this monument.

A formal geological identification of the slab was undertaken by Andrew Haycock of the National Museum of Wales. Two standard thin sections were prepared from small fragments taken from the back of the stone with permission from Meryl and Jerry Butler, allowing a more detailed examination. The lithology of the sandstone was found to closely match the Cefn Sandstone, a local Carboniferous age Coal Measures Sandstone. The nearest available significant source of Cefn Sandstone to Valle Crucis can be found just over 6 miles by road to the east at Cefn-mawr. The Cefn Sandstone outcrops extensively on the east side of Ruabon Mountain in this region, it is therefore reasonable to conclude it has a source in this local lithology.

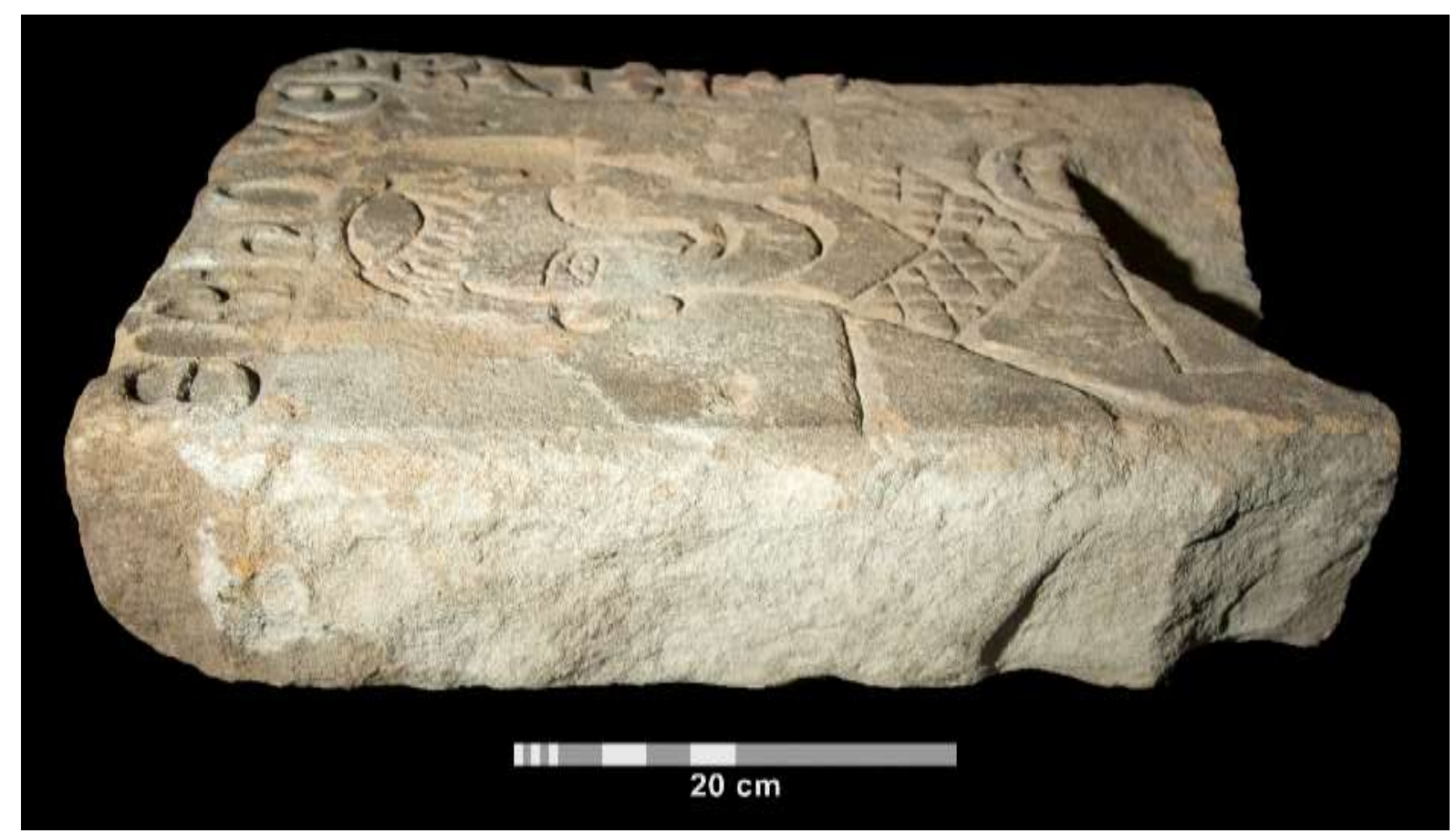

Illus. 4 The cut-down left-edge of the slab removing the original lettering. (Photograph: Aaron Watson, 2017)

The lower half to two-thirds of the monument (presuming it was originally of standard adult body-length) has been lost. Likewise, it appears that the left edge of the stone has been later dressed down (Illus. 4) leaving only two original edges: to the top (Illus. 5) and right sides (all descriptions take a viewer's perspective unless otherwise stated) (Illus. 6). The top edge shows clear signs of diagonal tool marks. The right edge has only feint tool marks and seems significantly worn. Both top and right edge bear clear evidence that the base was bevelled (Illus. 7). This base is relatively smooth, again bearing striations indicative of dressing at a diagonal angle (Illus. 8). 
Some of the lines of the carving are particularly broad, perhaps evidence of redefinition, maybe at a later date. This is most noticeable around the chin and upper body, but there is no indication that the figure has been substantially altered. There are multiple kinds of evidence of damage to the stone's carved surfaces, most likely occurring while it was exposed lying flat and face-up, and then during successive stages of removal. From the front face, there is a 'stab' mark to the right of the figure's head and one in the left collar area (Illus 2 and 3 ). There is also damage to the lower half of the upper face and surface flaking. Furthermore, the left side of the upper face is worn and chipped in places, thus obscuring some features. At the bottom of the upper face of the slab there is a scoop, perhaps suggesting its reuse at some stage in its later life-history, although it is unclear whether this happened before or after its fragmentation from the lower half of the stone (Illus 9, 10 and 12). There are two trapezoidal areas of damage, one over figure's left ear and to the left of the head; these might be damage caused by moving the slab with a forklift (Illus 2 and 3; Meryl and Jerry Butler, pers. comm. 2016). There is subtle reddening on the lower right side of the stone (Illus 6 and 10), possibly caused by the stone's exposure to intense heat, although there is no way of telling at what stage of the stone's life-history this took place.

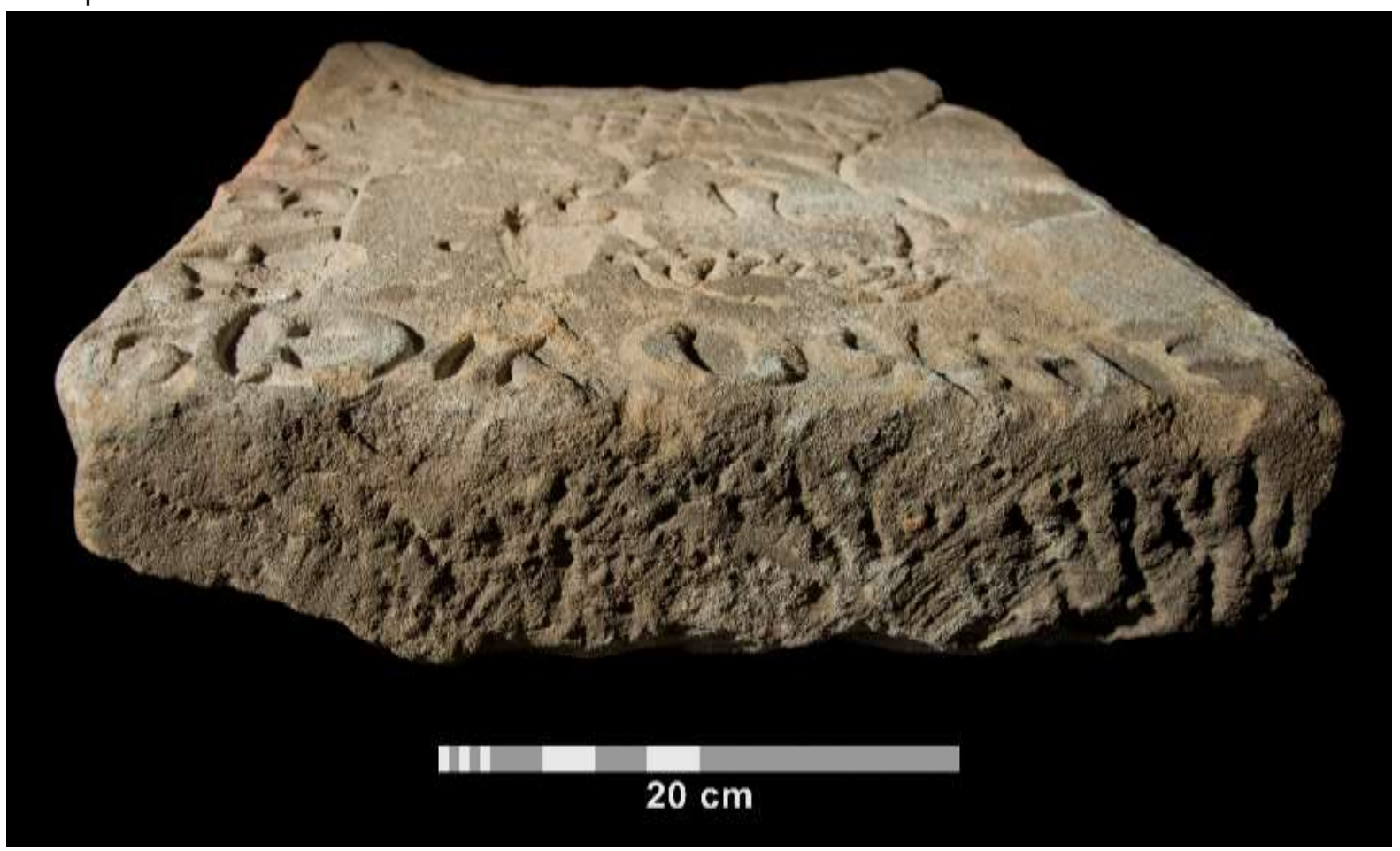

Illus. 5 The worn but original top-edge of the slab. (Photograph: Aaron Watson, 2017)

The stone lacks wear over much of its top surface, although wear does occur on the lower right side of the monument where the letters are faded, possibly evidence of foot or hand abrasions when originally installed in an ecclesiastical space, whether on a floor or recess. Damage to the left-hand edge is evident as the bases of letters can be discerned, removed 
when the stone was dressed down. At the bottom-left of the stone are two clear large chips into the side of the stone and there are three smaller chips along the top edge of the base (Illus 4 and 8). All these are consistent with one or more occasions when the stone was levered upwards, perhaps with a crowbar. The top left-hand corner of the stone has a large chip out of it, again perhaps created during the stone's removal from its original place of installation (Illus 4, 5 and 7). Finally, the stone's upper and lower faces, and sides - including the left-hand side that has been dressed down at a later date - are covered in a thin layer of lime mortar, perhaps relating to the stone's architectural reuse (the authors thank Andrew Haycock for confirming this observation). In summary, the stone bears witness to many complex stages of display and reuse, including perhaps as building stone following its removal and reworking.

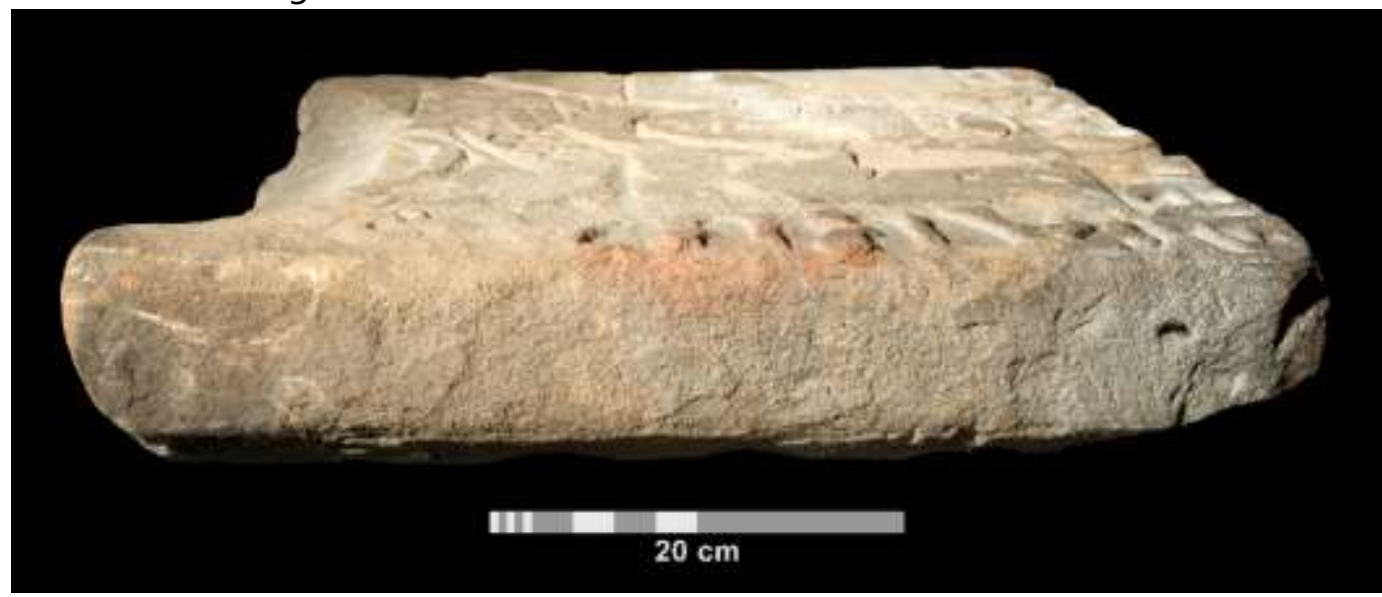

Illus. 6 The smoothed but original right-edge of the slab with chips at the top (right) side. (Photograph: Aaron Watson, 2017)

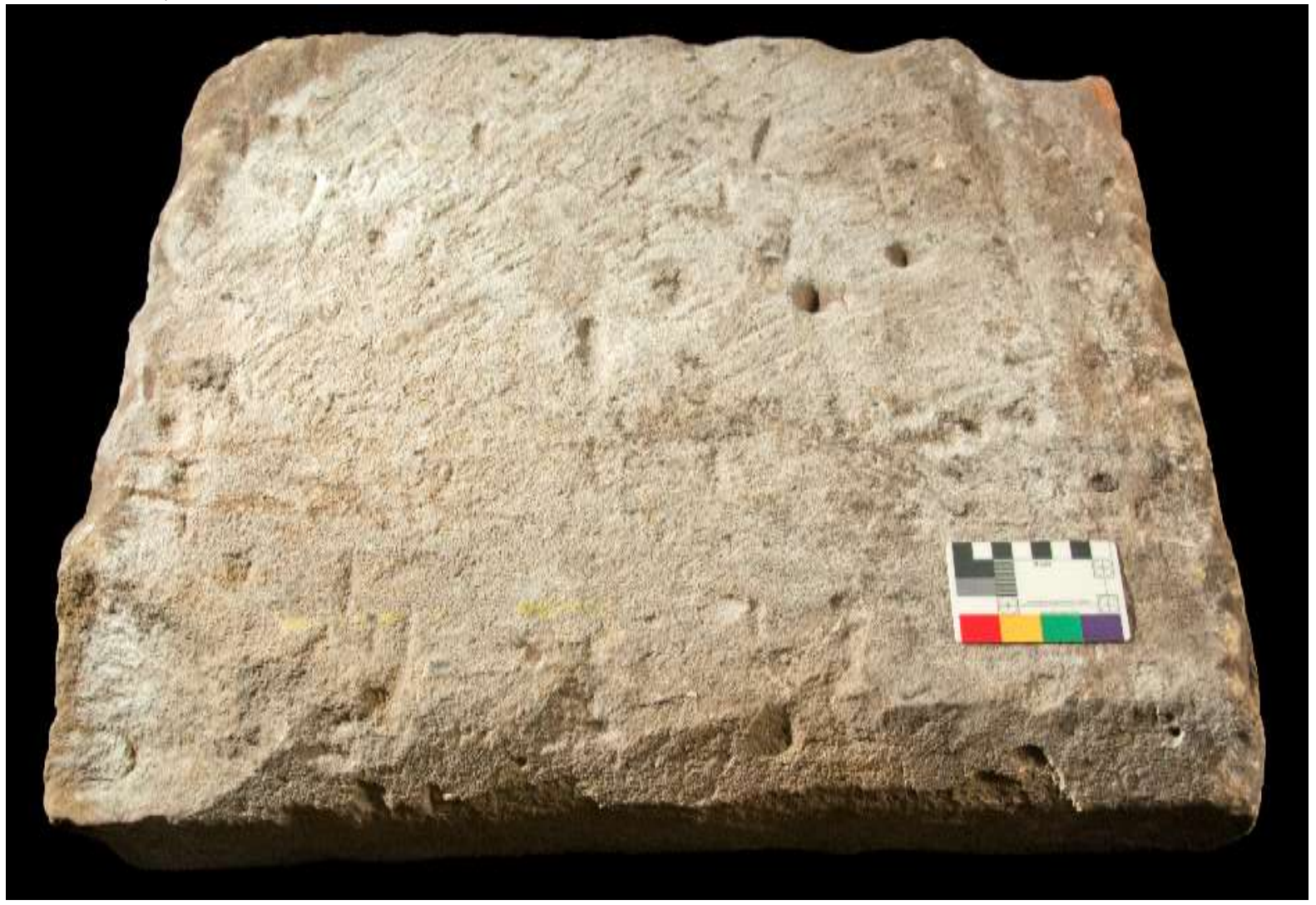


Illus. 7 The back/lower-side of the stone from an oblique angle showing bevelled edges. (Photograph: Aaron Watson, 2017)

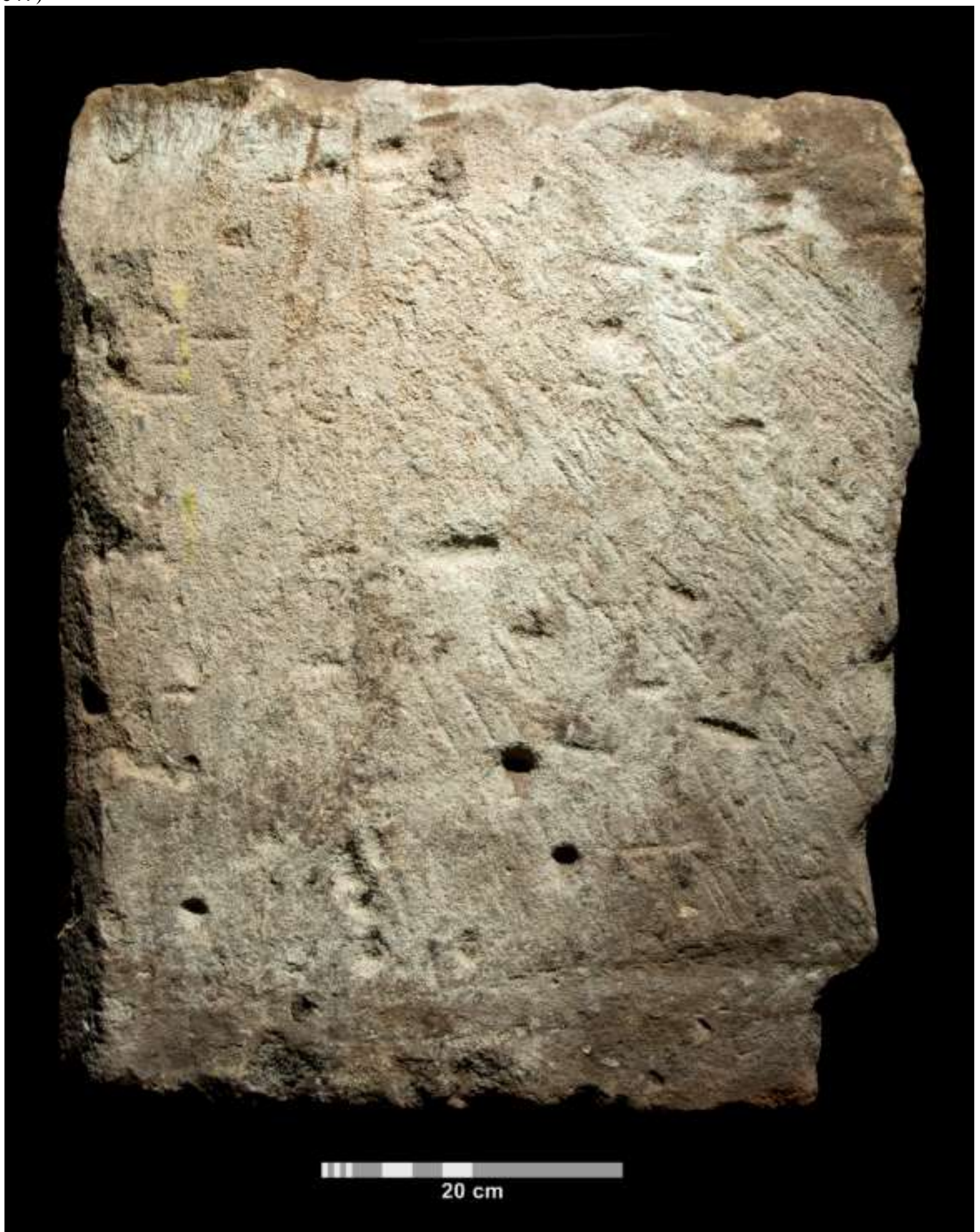

Illus. 8 The back/lower-side of the stone, showing striations from dressing and various horizontal cuts and dints. (Photograph: Aaron Watson, 2017) 


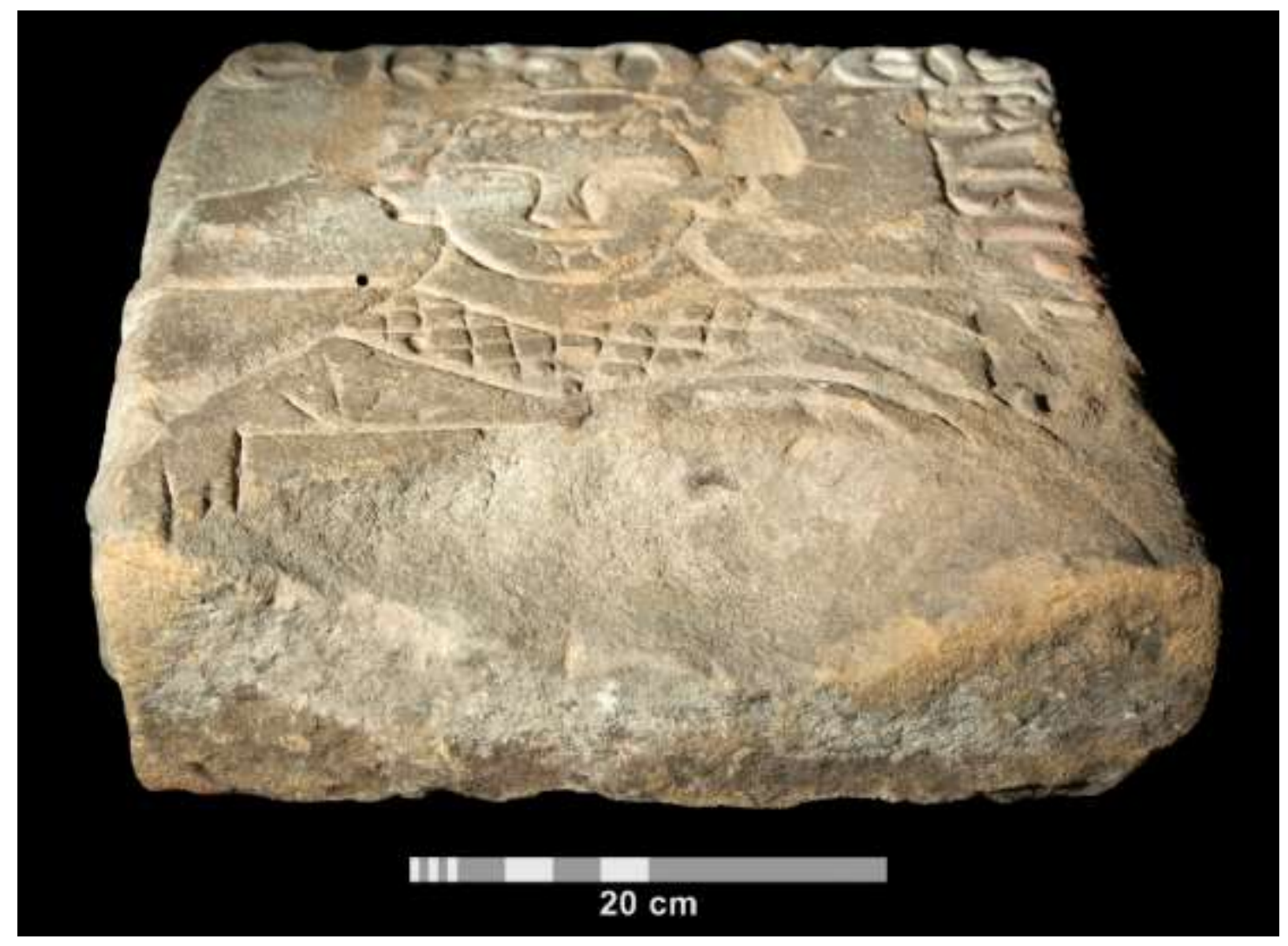

Illus. 9 The broken bottom edge of the slab, showing the scoop that has removed the chest area of the effigy. (Photograph: Aaron Watson, 2017)

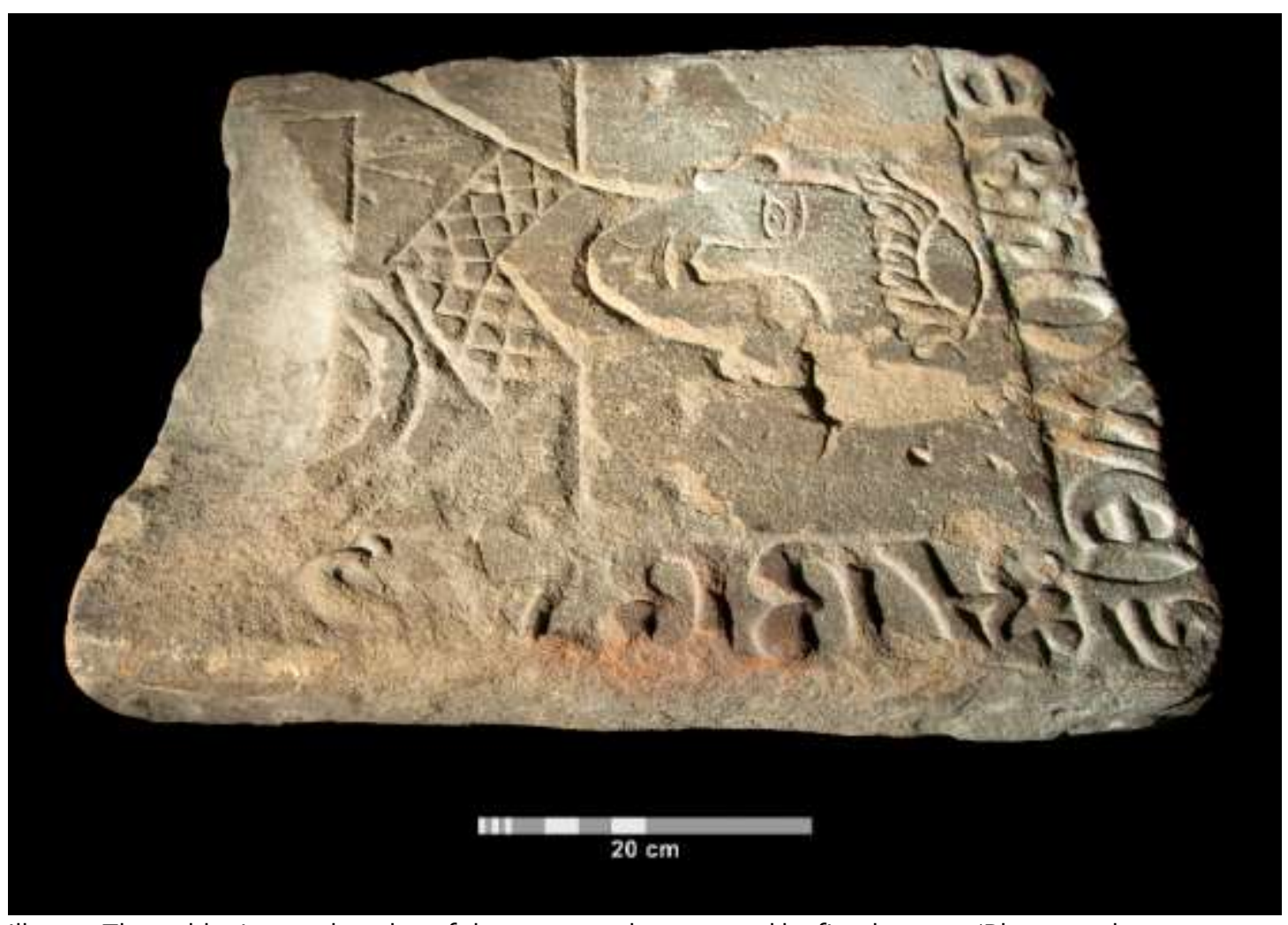

Illus. 10 The reddening on the edge of the stone, perhaps caused by fire damage. (Photograph: Aaron Watson, 2017) 


\section{The Head}

The figure's freehand carving is deep, bold and simple. The oval head of the figure is resting on a single pillow represented in two dimensions by a rectangular outline (Illus 2, 3 and 11). The figure is presumably male and his tonsure is apparent, with head-hair marked by nine curling short locks of varying length, thus creating a short high curtain over the forehead. Seven of these strands curl to the right, but the two on the left curl to the left. Between these strands and the ears, there are very faint indications of further incisionmarking blocks of hair between the tonsure and the ears (although partly obscured on both sides by later damage and therefore not reproduced in Illus. 23n).

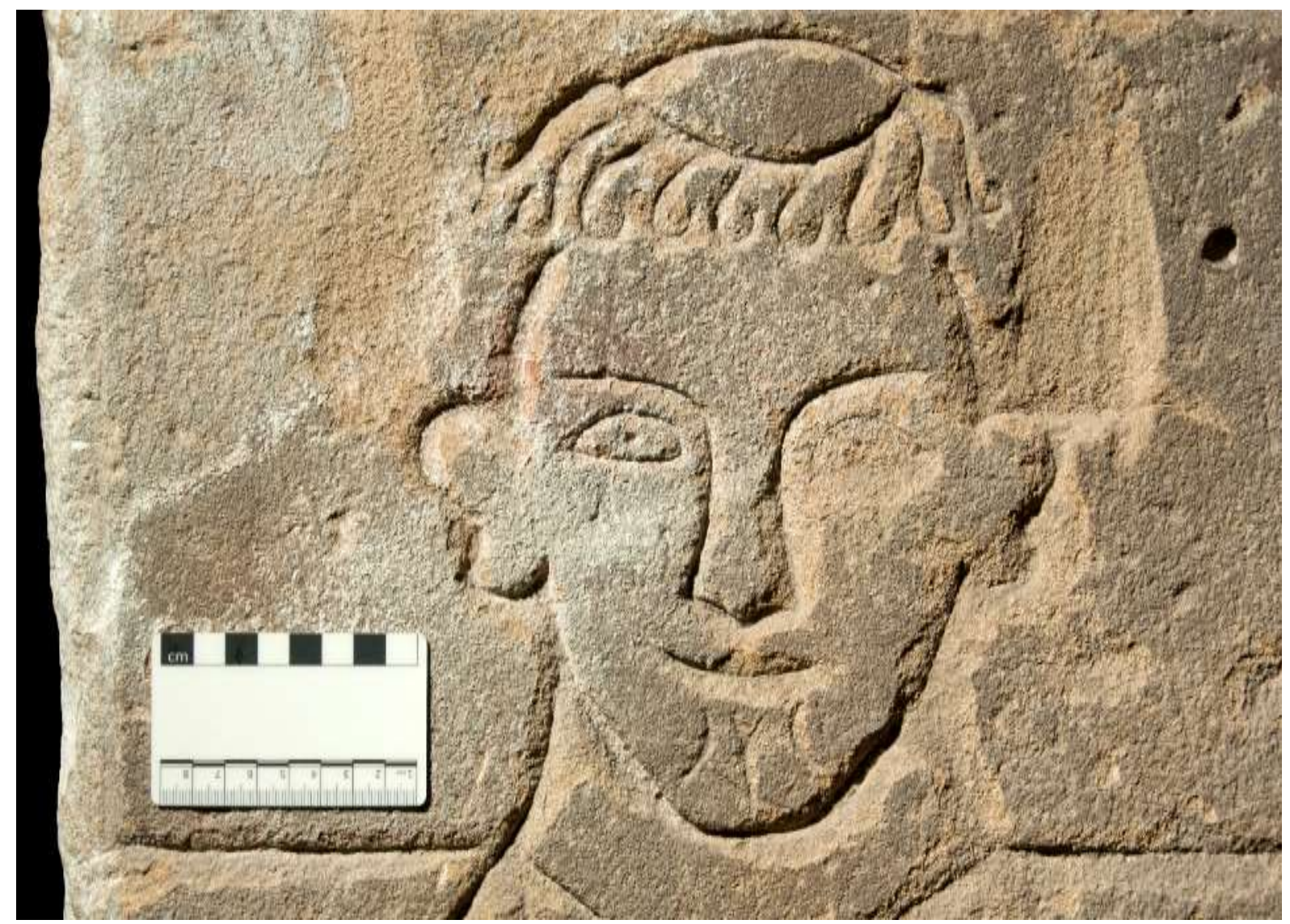

Illus. 11 Close-up of the head of the effigy, lit from top-left. (Photograph: Aaron Watson, 2017)

The figure's eyes are strikingly large and widely spaced, although the figure's left eye (viewer's right) is part obscured by later damage to its lower side. The pupils are both marked by a single incised dot. The eyebrows are slightly asymmetrical with the figure's left (viewer's right) raised higher than the other.

The nose is clearly depicted with a wide bridge joining the eyebrows. Again, there is asymmetry in the line of the nose and the angle of the nostrils due to the freehand carving. The ears are crudely drawn, distinctive and large, and irregularity is here once again apparent: the viewer's left is longer and thinner than the shorter fatter right. 
The most distinctive feature of the effigy is a discernible, if somewhat lopsided, smile. Upon the figure's squared chin are displayed three strands of hair, one central created by two lines joining together in a ' $Y$ ', and one to each side created by single incised lines. Together, these lines are suggestive of a small beard, although it is possible that the aim of the central lines was to denote a cleft chin.

In summary, the figure's head is simple, rendered idiosyncratic and asymmetrical, resulting from freehand sketch work. A religious identity is apparent and a lunate mouth makes the presence of a smile indisputable.

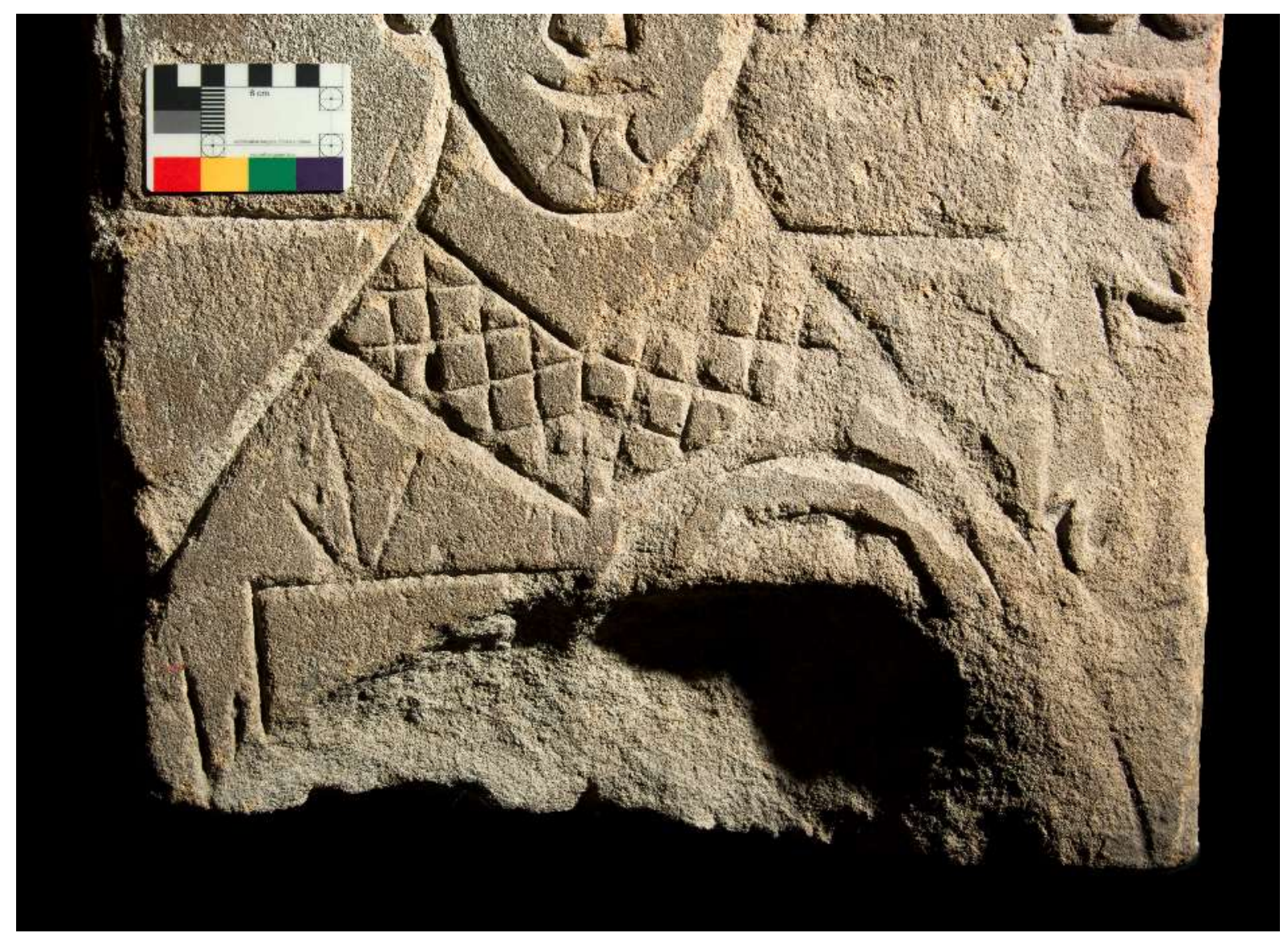

Illus. 12 The lower part of the stone, showing details of costume, book, possible paten and the letters A and S. (Photograph: Aaron Watson, 2017)

\section{The Body and Possible Artefacts}

Our appreciation of the figure's body is restricted by the later damage to the monument (Illus 2, 3 and 12). The figure's neck is broad and thus presumably depicting clothing: a plain amice. He wears a diamonded orphrey with a vertical line breaking the pattern down the centre-line of the body, denoting where the garment was joined (cf. Greenfield 1976, $72-$ 76). His chasuble has folds denoted by two sets of radial lines. On the right (figure's left), the line of the body can be followed to the bottom of the stone and within $2 \mathrm{~cm}$ of the outer edge of the monument. Rather than wearing a monastic habit, it is evident that this figure is depicted in Mass vestments. 


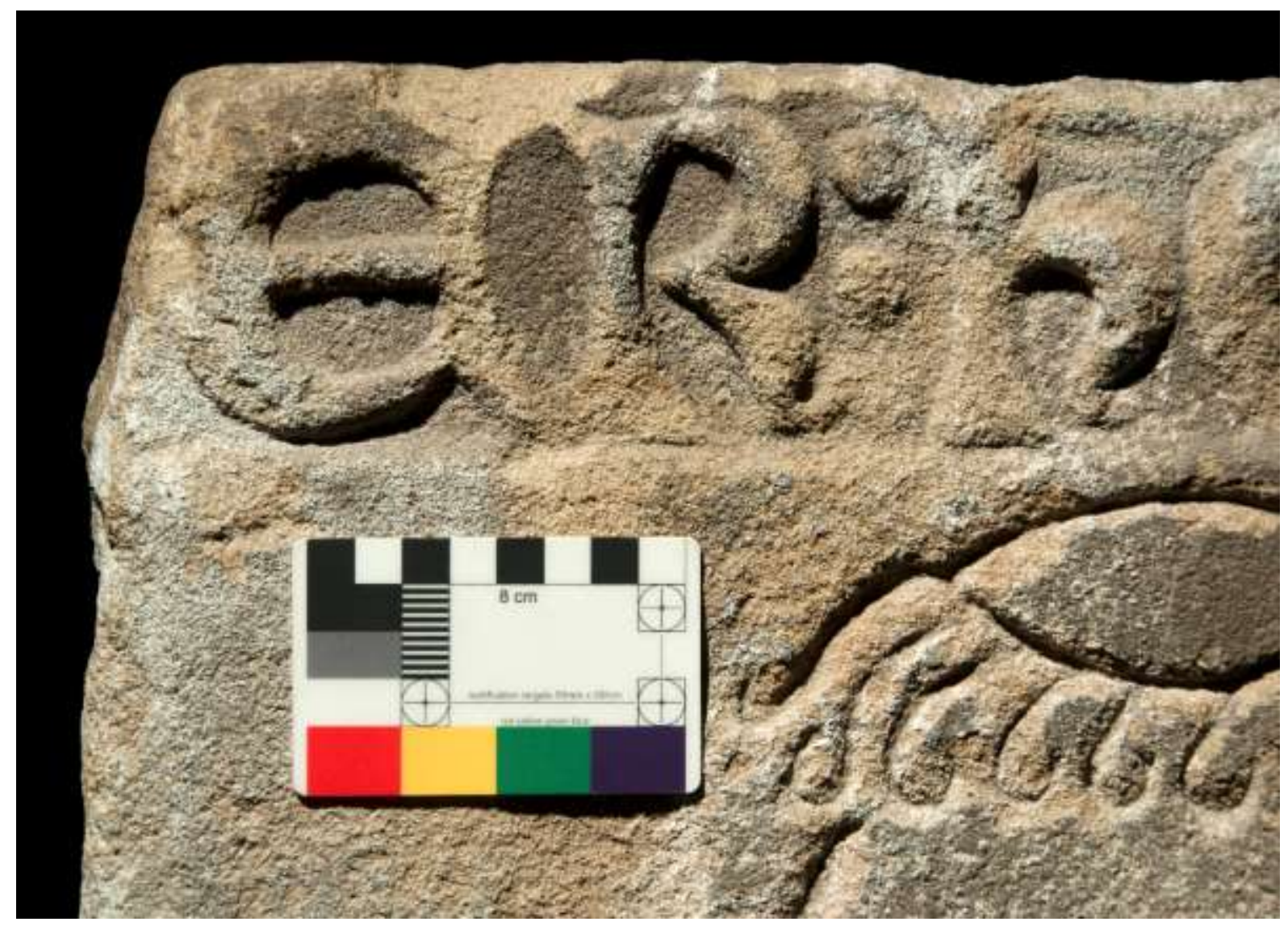

Illus. 13 Close-up photographs of the letters ER: H. (Photograph: Aaron Watson, 2017)

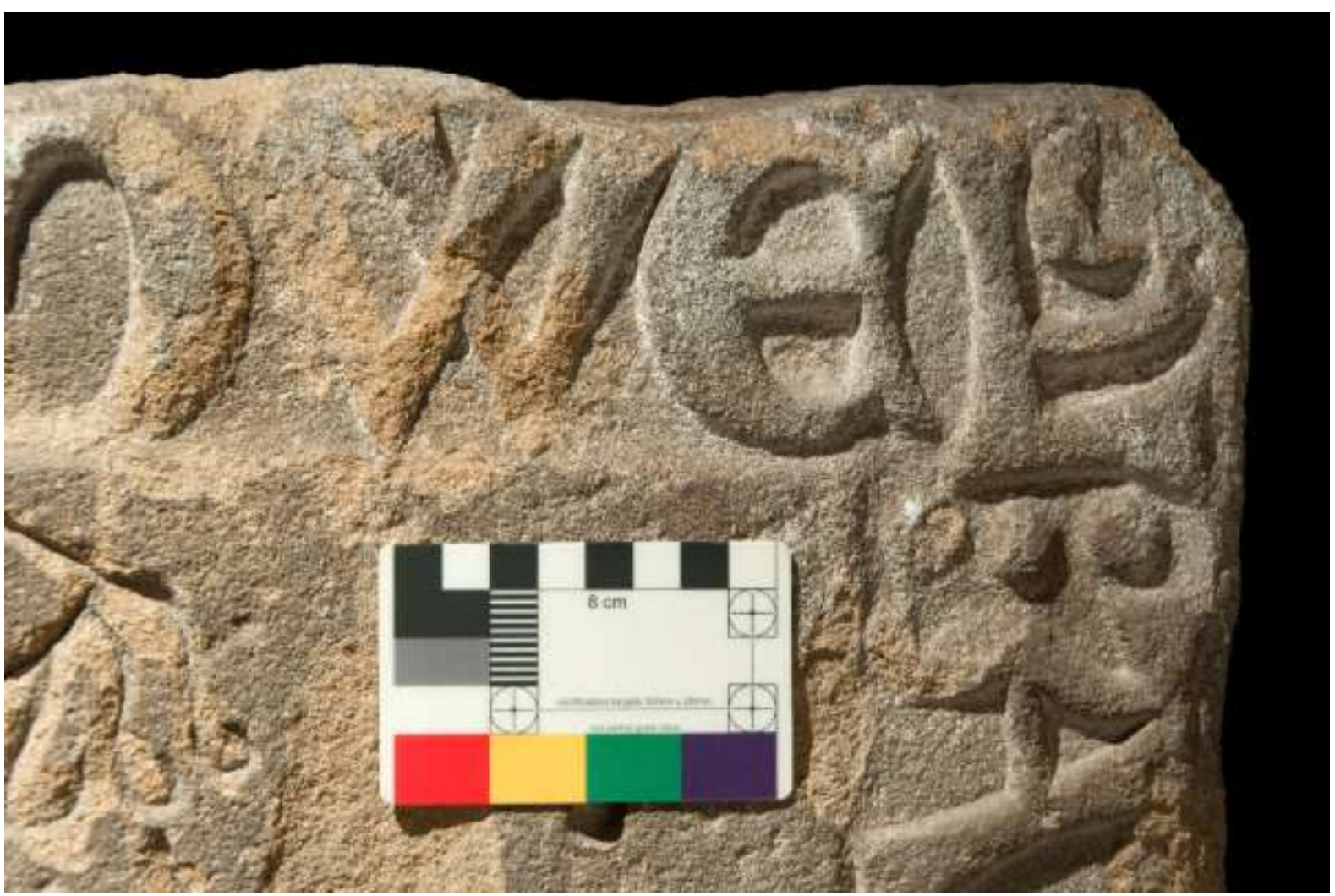

Illus. ${ }_{14}$ Close-up photographs of the letters WEL': A. (Photograph: Aaron Watson, 2017) 


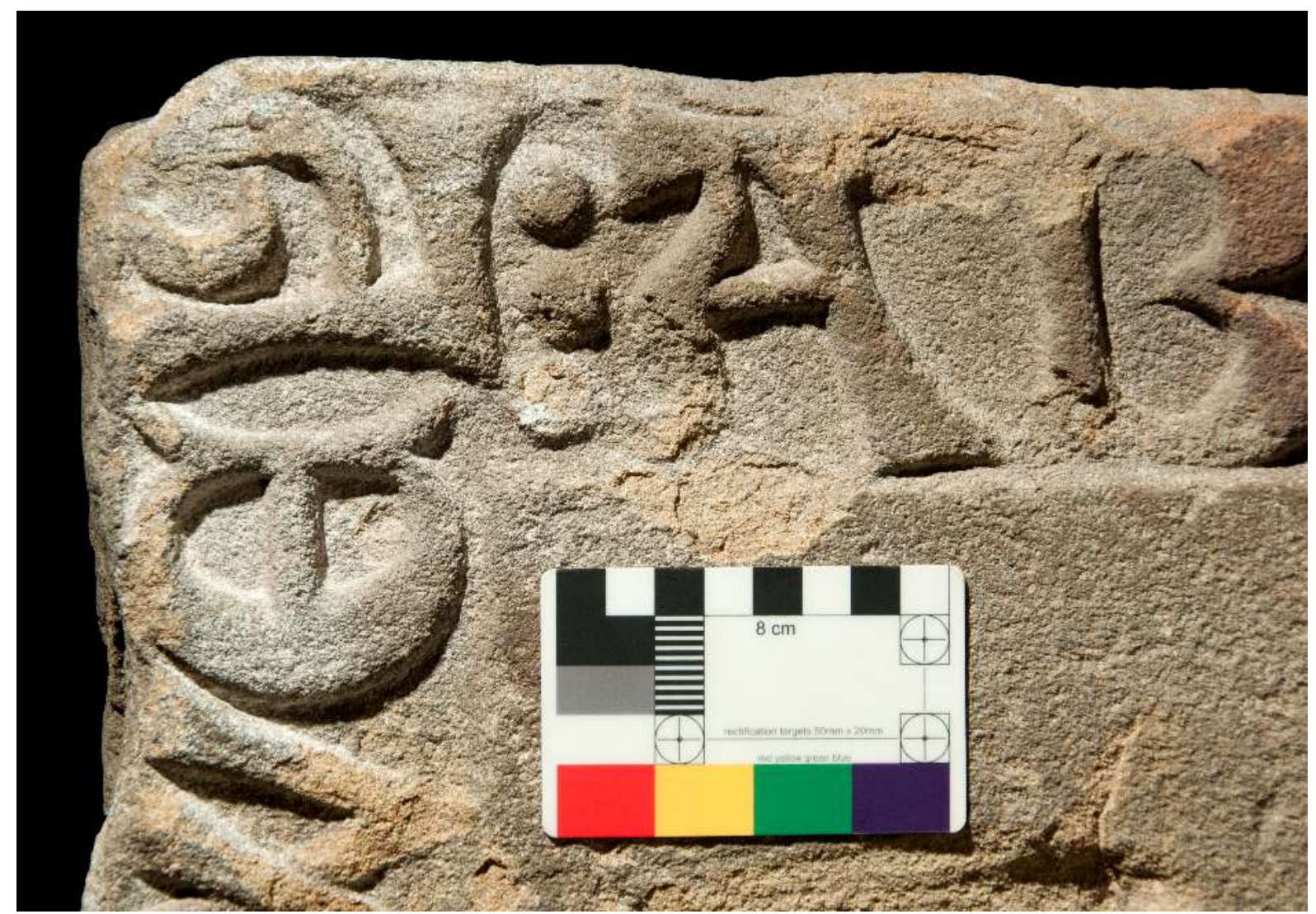

Illus. 15 Close-up photographs of the letters EL': AB. (Photograph: Aaron Watson, 2017)

The connected vertical and horizontal lines on the lower left of the stone (right side of the figure's body) might be the top and side edges of a Bible or missal, held in the (now obscured) right hand (Illus. 12). Although partly removed by later damage, it is possible there is a vertical line (shown in Illus. 1) running down from the top edge on the right side: this might denote the book's spine (Illus 1 and 12).

To the lower right (figure's left), the surviving stone shows an arcing object, emerging with, and paring off from, the outer right-side (figure's left) of the figure's garments (Illus 2, 3 and 12). This might be a poorly depicted crozier, but for this to work the artefact would have to be depicted oddly positioned far down on the upper body. A crozier in the left hand might be expected to appear beside the head rather than over the chest (Badham 2011, 14-15) although Badham and Oosterwijk (2015, 18-19) do provide some Continental exemplar where the heads of croziers are resting on the upper torso, albeit in locations closer to the head than in our case. However, S. Williams (1895) proposed this to be a paten, seen from above. We find this interpretation more convincing given the internal traces of what might be a fragment of a hexafoil design: a common feature of medieval patens (Illus. 12). One foil is visible and perhaps to its right the start of a second one. We know of no precise parallel for this arrangement in effigial art, making this a particularly distinctive 
representation of a medieval monastic.

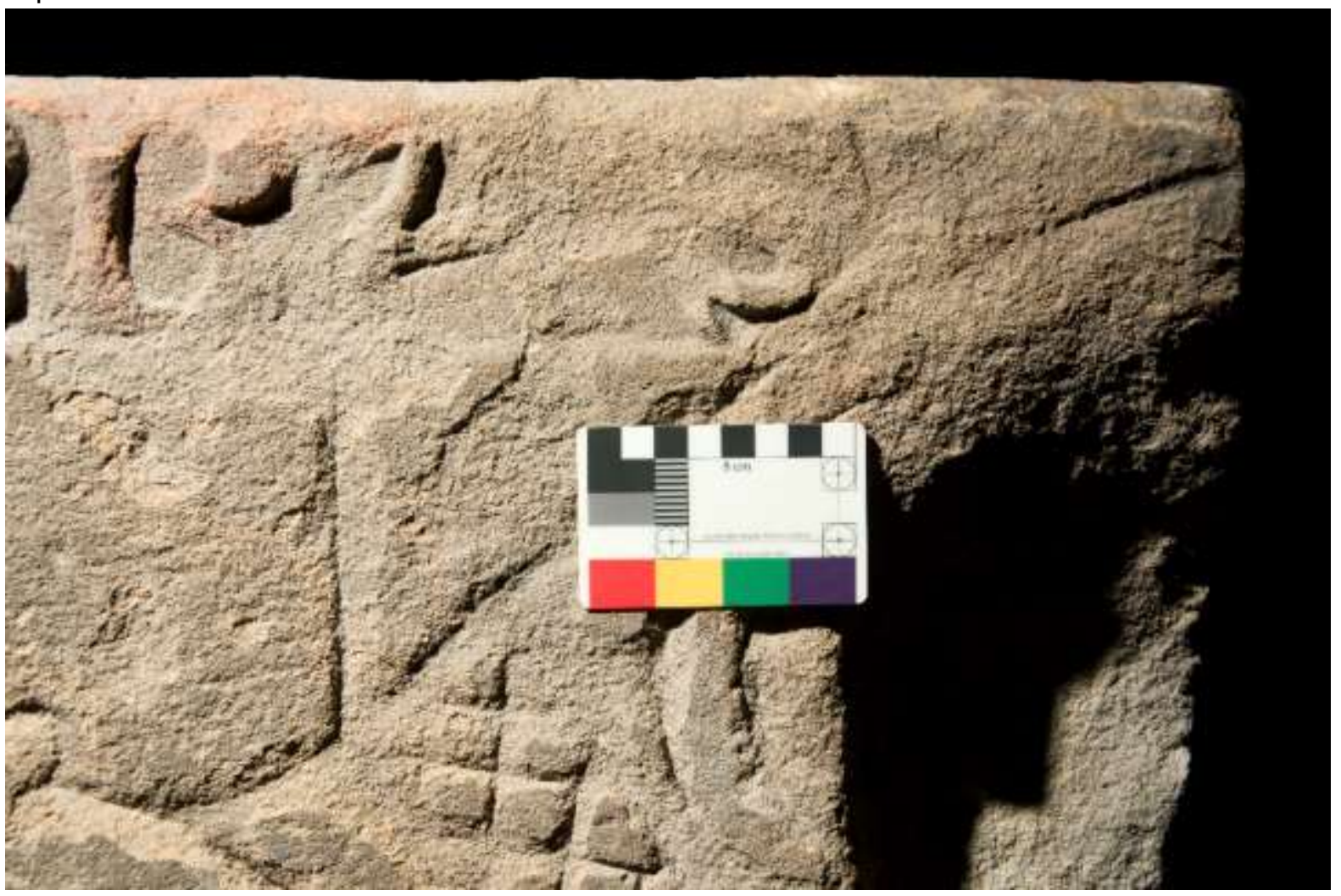

Illus. 16 Close-up photographs of the lettering BAS. (Photograph: Aaron Watson, 2017)

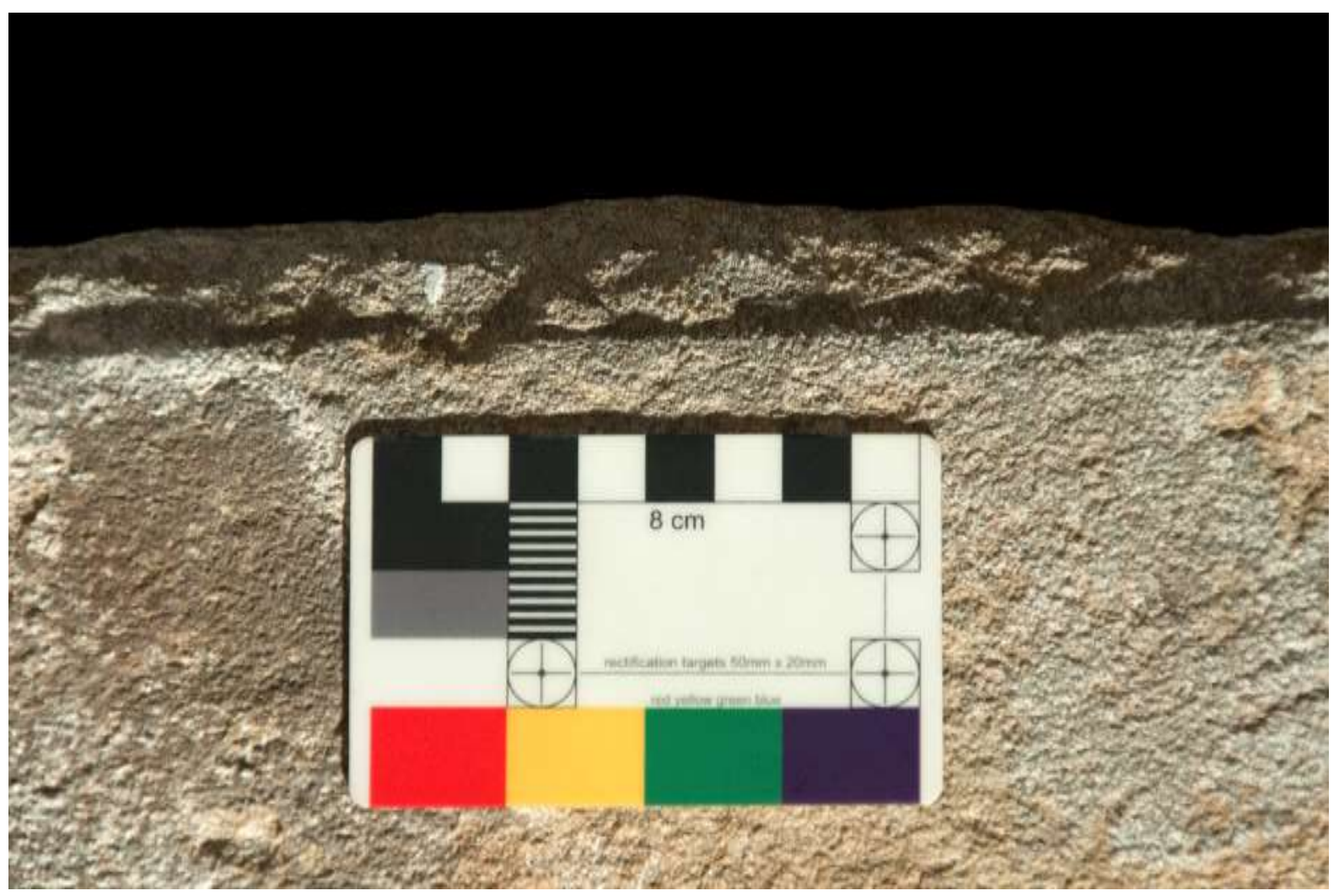

Illus. 17 Close-up of left-hand edge of the top-face of the stone, showing possible traces of the base of letters, as more clearly revealed in the 1895 published line drawing. (Photograph: Aaron Watson, 2017) 


\section{Epigraphy}

S. Williams $(1895,125)$ noted that the epigraphy is better executed than the figure itself. This inference leaves open the possibility of multiple carvers, or at least one carver able to utilize templates to guide the letter-carving but less able to execute the freehand carving of the figure. The script is a Latin memorial: Lombardic majuscules carved in false relief (Illus $2,3,13-17)$. This style is commonly dated to the last quarter of the thirteenth century and persists through much of the fourteenth century AD in North Wales. In contrast, this epigraphy is rarer, and more rapidly succeeded during the early fourteenth century by textualis script in South Wales and England (Gresham 1968, 25; Gittos and Gittos 2012). The surviving text (Illus. 9), like the stone, is therefore a fragment:

\section{...ER: HOWEL': ABBAS}

A triplet of vertical pellets mark the spaces between words: a common feature for Lombardic majuscules on mortuary monuments in the region. The drawing published with S. Williams's article also notes two pellets after the S. However, these are no longer convincingly discernible despite careful examination by the authors (S. Williams 1895, 124). Above and right of the $L$ is a large 'apostrophe' denoting a contraction of the name, which S. Williams $(1895,124)$ speculated might indicate a Latinization of 'Howel' to 'Howelas'.

By analogy with many memorials found in the region, such as those from Valle Crucis Abbey, we must anticipate that text originally ran along the now-lost viewer's top-left edge of the slab too and began with the Latin 'hic iacet' ('here lies') commemorative formula. Indeed, S. Williams $(1895,124)$ suggested the presence of the bottoms of three or four letters ran along the stone's left side. As noted above, the evidence is more ambiguous today, but under very careful examination these letters can be discerned (Illus. 17). The line of the figure's body blocks any further letters down the right side of the monument, suggesting that ABBAS was the last word of the memorial inscription. Putting these lines of evidence together, a suggestion for the original inscription is:

\section{HIC IACET FRATER HOWELAS ABBAS}

Here lies brother Howel, Abbot

\section{Provenance}

The monument was discovered, and then purchased by the present owners, in a sale of miscellaneous building materials in the yard at Wynnstay Hall in the 1980s, when Lindisfarne College owned the Hall. The name's linguistic/ethnic affiliation and the title 'abbas' (abbot) clearly point to the stone having come from a Welsh abbey. 


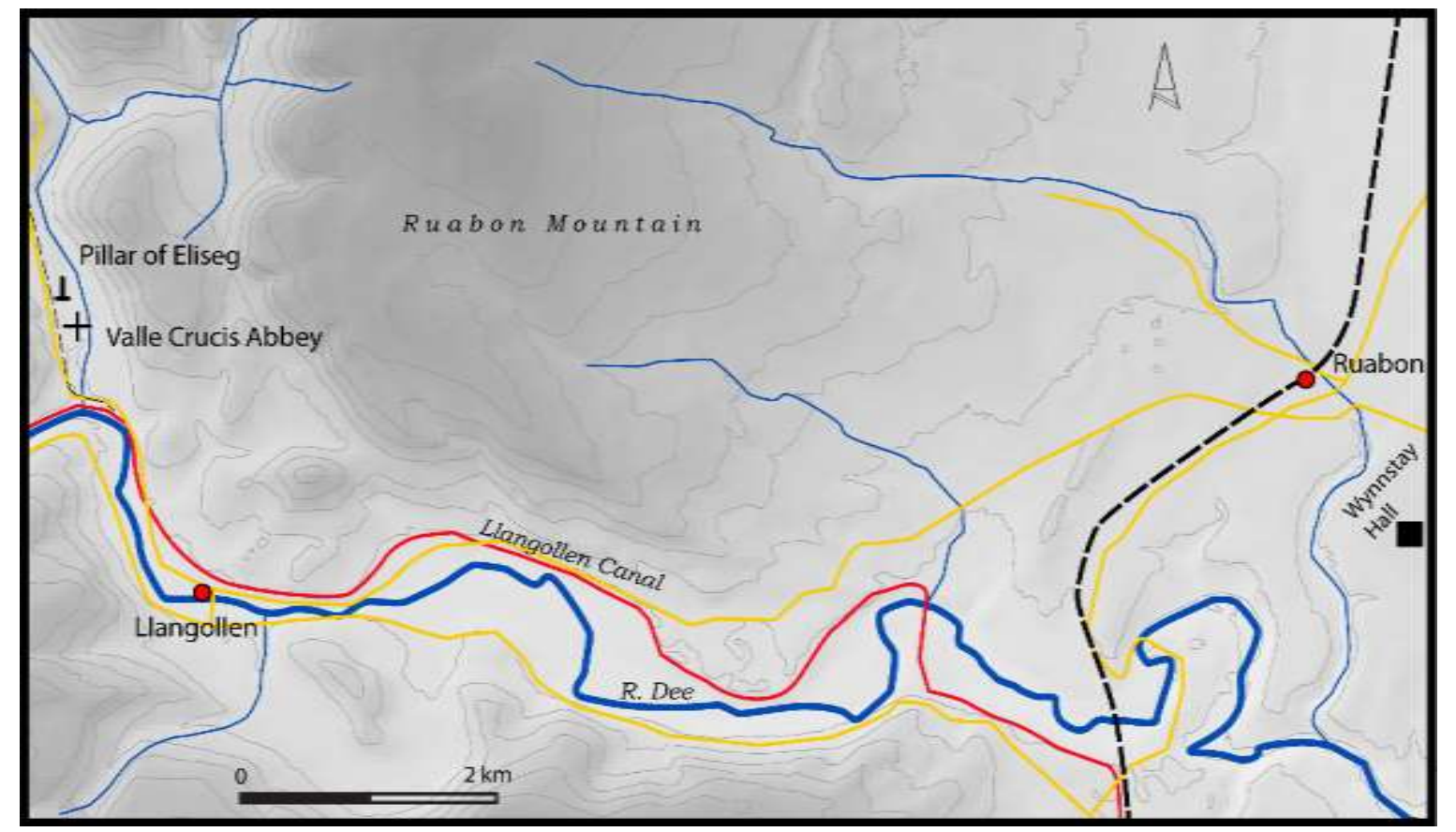

Illus. 18 Map of the location of Valle Crucis in relation to Wynnstay Hall, showing routes available in 186o. Yellow = roads; thick black dashed line = principal railway lines; thin black dashed line = tramway; blue $=$ water courses, red = canal. (Map drawn by Howard Williams with guidance from David Crane)

Over the centuries, the Wynnstay estate, or the families from whom the Williams Wynn family were descended, owned land in Caernarfonshire, Cardiganshire, Denbighshire, Flintshire, Meirionethshire and Montgomeryshire, as well as in Shropshire, Cheshire, Buckinghamshire, London, Warwickshire, and Yorkshire. They also had connections with, and relatives in, South and West Wales, including Carmarthen. Hence, the family held land in the vicinity of many medieval religious houses, including some of the leading Cistercian abbeys of Wales, notably Aberconwy, Basingwerk, Cymer, Cwmhir, Strata Marcella, Strata Florida and Valle Crucis. They also had relatives who lived near Whitland (another Cistercian abbey) and Talley Abbey (a Premonstratensian foundation) (Roberts 1876).

In his 1895 paper, as noted above, Williams states that the slab 'is now at Wynnstay, and said to have been brought from Caer Gai' (S. Williams 1895, 124). Caer Gai Roman fort is located just outside Llanuwchllyn, at the south-west end of Llyn Tegid. In 1840, the land on which the fort was located was not enclosed but it did belong to Sir Watkin Williams Wynn - so if the stone was found at Caer Gai, then it is quite possible that it was discovered and transported to Wynnstay. If this is the true scenario then the key questions are: from whence, how and why did the stone get to Caer Gai?

That there may have been a monastic house at Caer Gai as a suitable venue for an abbatial monument and totally unknown to scholars is extremely unlikely (see Burton and Stöber 2015, 10-13). However, less than 12 miles to the south-west of Caer Gai lie the ruins of Cymer Abbey (ibid., 84-86) and it remains a possibility that the effigial slab was from that Cistercian house. Admittedly, no abbots of that name are recorded at Cymer Abbey but there are some quite large gaps between the dates of known abbots of Cymer Abbey in the 
thirteenth century into which an unknown Howel/Hywel could possibly fit. However, it is also quite possible that Williams' uncorroborated source was mistaken and that the stone got to Wynnstay from another abbey, the most likely location being Valle Crucis Abbey. This is supported by the aforementioned geological identification which links the monument as Cefn Sandstone, most likely quarried where it outcrops at Trefor near Ruabon.

Therefore, it appears there is no archaeological or historical logic to the monument deriving from Caer Gai. Instead, in 1851, Lord Dungannon and William Watkin Edward Wynne carried out the clearance of a large part of Valle Crucis Abbey, removing up to 14 feet of earth and stone fromthe church building. In a report of the clearance by the architect R. K. Penson to the Cambrian Archaeological Association, he says that: 'Mr Wynne described a very beautiful incised slab which was found near one of the pillars of the tower; although broken into several pieces, the carving was sharp and perfect and what remained of the inscription was quite legible' (Penson 1851b, 329-30). Although he does not say what the inscription was, it seems almost certain that this is the tombstone referred to by W. W. E. Wynne earlier in the same volume (Penson 1851a, 283) as being that of Edwart fil lorwerth (Gresham 124: Gresham 1968, 141). In that same report Wynne says that, apart from a fragment bearing the greater part of the name Myfanwy (not subsequently identified: Penson 1851a, 283), and the grave-slab reused as a lintel (Penson 1851a, 284; Gresham39: Gresham 1968, 89), other portions of sepulchral monuments were found but none were worthy of description (e.g. Gresham 1968, 82-3). It seems unlikely, therefore, that the grave-slab under consideration here was identified during the clearance by Wynne and Dungannon.

Between 1880 and 1910 the custodian, the Rev. H. T. Owen, carried out much clearance and excavation of Valle Crucis Abbey. He found a number of tombstones but none are mentioned that match with the stone under consideration here (Oswestry Advertiser, January 21, 1894; Byegones, June 6, 1894; Byegones, November 21, 1894; Byegones, March $14,1900)$. The same applies to the reports by the historian Alfred Palmer (1889) about Owen's findings (Gresham 1968, 79-80, 86, 108). Among the later clearances of Valle Crucis Abbey by the Ministry of Works in the 1950 and 1960 , and the excavations by Butler in 1970 and 1971 (Butler 1976), no decorated slab of this description was recovered.

This negative evidence does little to discount Valle Crucis as a likely source for the stone, however. In the centuries following the Dissolution of the Monasteries in 1536, it was common for stone to be reused as building material in the local area and it is possible that the slab had left the abbey before the nineteenth century. In this regard, the original halftimbered house at Wynnstay was replaced with a stone hall in the 1720 s and a number of extensions and improvements were made over the next 150 years. The most significant rebuild was, however, between 1859 and 1865 , following a disastrous fire in 1858 that totally destroyed the building (Pritchard 1982, 96-132). At this time materials were brought in from many places, including Shropshire, but stone for chimney pieces was purchased from the Llangollen Slab and Slate Company and while much of the stone at Wynnstay was 
quarried close by and comprises of Coed-yr-Allt sandstone, it is possible the Smiling Abbot - as a whole grave-slab or as a fragment - came to be displayed at Wynnstay during a programme of re-building. It had only been seven years before the fire that Lord Dungannon and William Watkin Edward Wynne had carried out the clearance of a large part of the nearby Valle Crucis Abbey: work commemorated upon an extant memorial plaque installed on the north-facing wall of the south-side of the nave to this day (Price 1952). Therefore, it is possible that the image of the Abbot was recognized and the stone was transported, perhaps as building stone, but more plausibly for its antiquarian significance.

William Watkin Edward Wynne was the nephew of Sir Watkin Williams Wynn, 3rd baronet of Wynnstay. Getting any stone to Ruabon would have been relatively straightforward. If not by cart or wagon, the movement of stone could have made use of the tramway taking slate down to the Llangollen Slab and Slate Company which had been completed two years before in 1857 (Thomas and Southern 2013, 35) and passed right in front of the abbey. At the slate works all of the necessary machinery was in place to transfer stones onto barges on the upper part of the Llangollen Canal. Stone might have been then taken to Wynnstay by the same route as the chimney pieces. The stone could have been transferred onto the newly built railway at a number of places between Pentre and Chirk to be taken by train to Ruabon, or even offloaded at Wynnstay Colliery, situated at the edge of Wynnstay Park (Illus. 18).

The fire damage might represent a further strand of evidence supporting the provenance of the monument at Valle Crucis, where reddened masonry indicates that a fire destroyed the conventual buildings in the mid-thirteenth century (Butler 1976, 80; Evans 2008, 19, 30-31, 33). However, given the likely early fourteenth-century date for the effigial slab (see below), the reddening might instead represent damage during a later and better-documented inferno in or before the period 1410-19 (Butler 1976, 80). Archaeological evidence of burning found during the 1970 excavations might represent traces of one or both of these conflagrations (Butler 1976, 84-85). For example, within the refectory, two discrete burning layers were discerned (Butler 1976, 88, 96). A further alternative is that the stone had reached Wynnstay Hall prior to 1858 when the house was destroyed by a fire, as mentioned above.

Alternative provenances for the stone cannot be ruled out conclusively, and the stone might have been transported to Caer Gai at the Dissolution before making its way to Wynnstay as S. Williams (1895) reports. However, especially given the geological identification as Cefn Sandstone, we propose Valle Crucis Abbey as by far the most likely place where the stone was originally displayed and the 1850 s as the most likely point at which the stone left the abbey for Wynnstay Hall. 


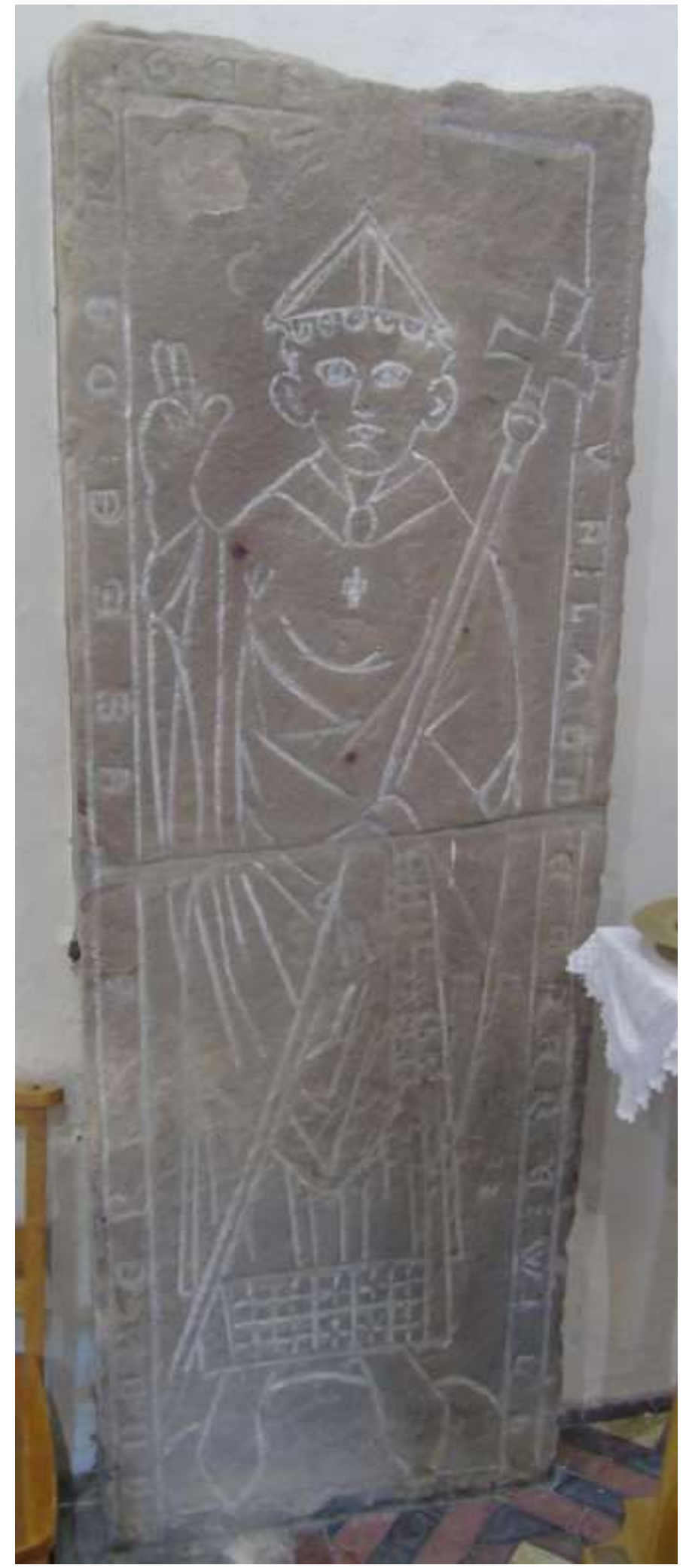

Illus. 19 The effigial slab of William de Freney, St Mary's Rhuddlan, dated to c. 1290. (Photograph: Howard Williams)

\section{Dating and Style}

Parallels for the Figure 
The authors have identified no exact parallel for the figural representation in terms of the facial features, hair style, dress or the combination of items seemingly held by the figure. Such a distinctive image might encourage scepticism regarding its authenticity. However, there are certainly a small number of very late thirteenth/early fourteenth-century ecclesiastical effigies and monuments from North Wales which deserve comment to establish authenticity and context, if not precise parallels (Gresham 1968). Perhaps the closest similarity exists between the abbot's representation and the very late thirteenthcentury (c. 1290: Gresham 1968, 161-62) Archbishop William de Freney effigial slab from Rhuddlan. Although this funerary monument uses inscribed, rather than false-relief, Lombardic majuscules, and the execution and posture of the figure are quite different, the simplified facial features including exaggerated ears and eyes are similar in broad terms (Gresham 1968, 160-62; Illus. 19; Illus. 23d). The finely worked semi-effigy of lorwerth Sulien vicar at Corwen, dated to c. 1340-50, contrasts in the figure's posture and the highquality plastic portraiture, although it bears a comparable false-relief Lombardic text to the stone under consideration here (Gresham 1968, 170; Gittos and Gittos 2012; Illus. 20). The remaining semi-effigial monuments from the region are distinctive and secular in subject: there is one from St John's Chester (Illus. 21) (Gresham 214: Gresham 1968, 239-41; Gittos and Gittos 2012, 367-70), another from Valle Crucis (Gresham 175: Gresham 1968, 186-88, Illus. 22), both dated to the mid-fourteenth century. There is also a semi-effigial civilian monument from Overton (Wrexham) which resonates with the 'Smiling Abbot' monument in its crude execution and smile; it could also date to the late thirteenth or fourteenth century (Gittos and Gittos 2012, 382). However, there are no directly comparable incised slabs from the region.

Looking beyond the region brings closer parallels in general terms for the figure's facial features (Illus. 23). The simple ears and eyes find no single or specific comparison beyond the de Freney monument. Yet the nose is paralleled in the very late thirteenth-century incised slab of Richard Duraunt (d. 1284) from Dunstable (Beds.) (Badham and Norris 1993, 124; Illus. 23b). The same applies to the priest's effigial slab for Richard de Greeton from Pyrton (Oxfordshire) (dated c. 1280-89) (Badham and Norris 1999, 120-23; Illus. 23C). Of particular note as a parallel, as much for the similarity of diamonded orphrey as facial features, is the incised slab of William de Williamstorpe (d. 1309) from Rothwell (Northants.) (Badham and Norris 1993, 80-81; Illus. 23e). Although far more refined in execution, the episcopal brass of Archbishop William de Greenfield (d. 1315) from York Minster deserves mention (Rogers 1987, 18; 58; Illus. 23f), although it is notable that this monument, and portrayals of priests dated to after the 1310s, offer no close similarity (Illus. $23 g-k)$. 


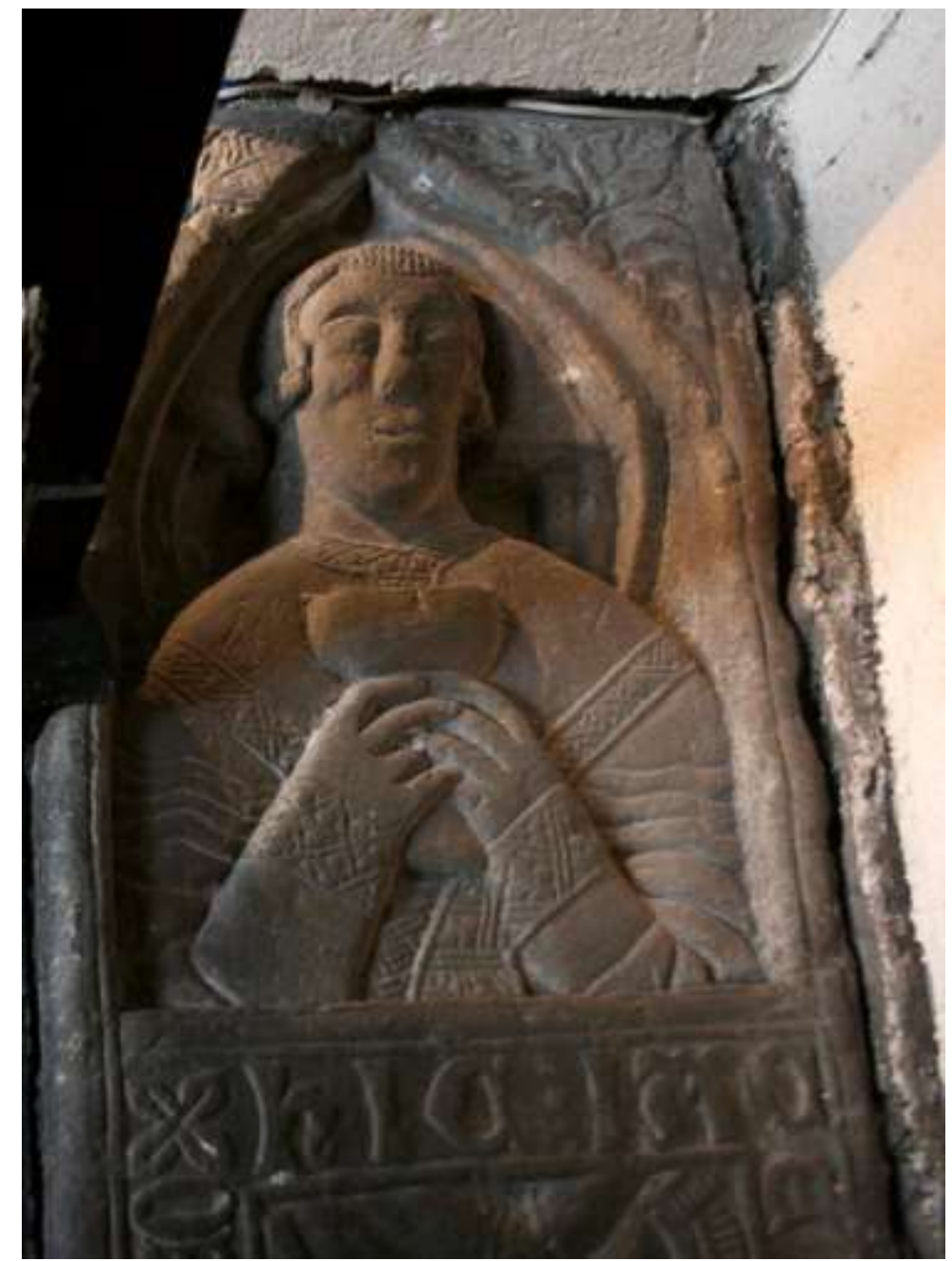

Illus. 20 The semi-effigial slab of lorwerth Sulien vicar at Corwen, dated to c. 1340-50. (Photograph: Brian and Moira Gittos)

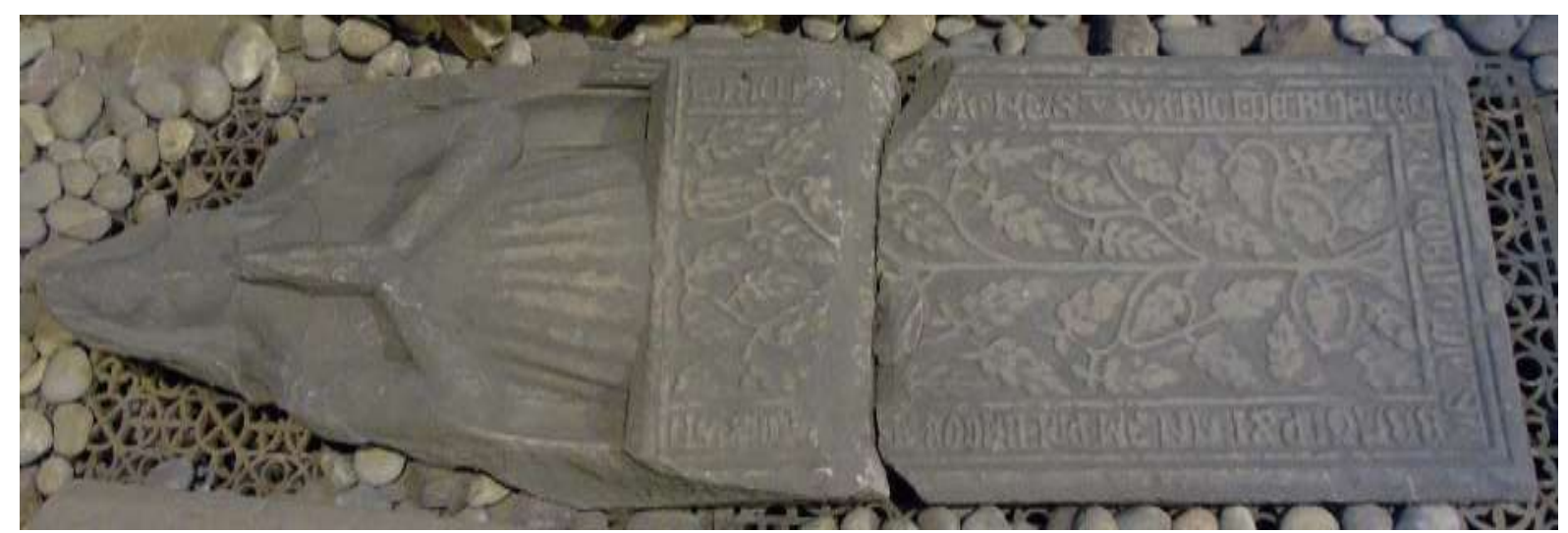

Illus. 21 The semi-effigial slab of Agnes de Rideleigh, St John's Chester, Gresham 214 (Gresham 1968, 239-41), dated to C. 1347 (Gittos and Gittos 2012, 367). (Photograph: Howard Williams) 


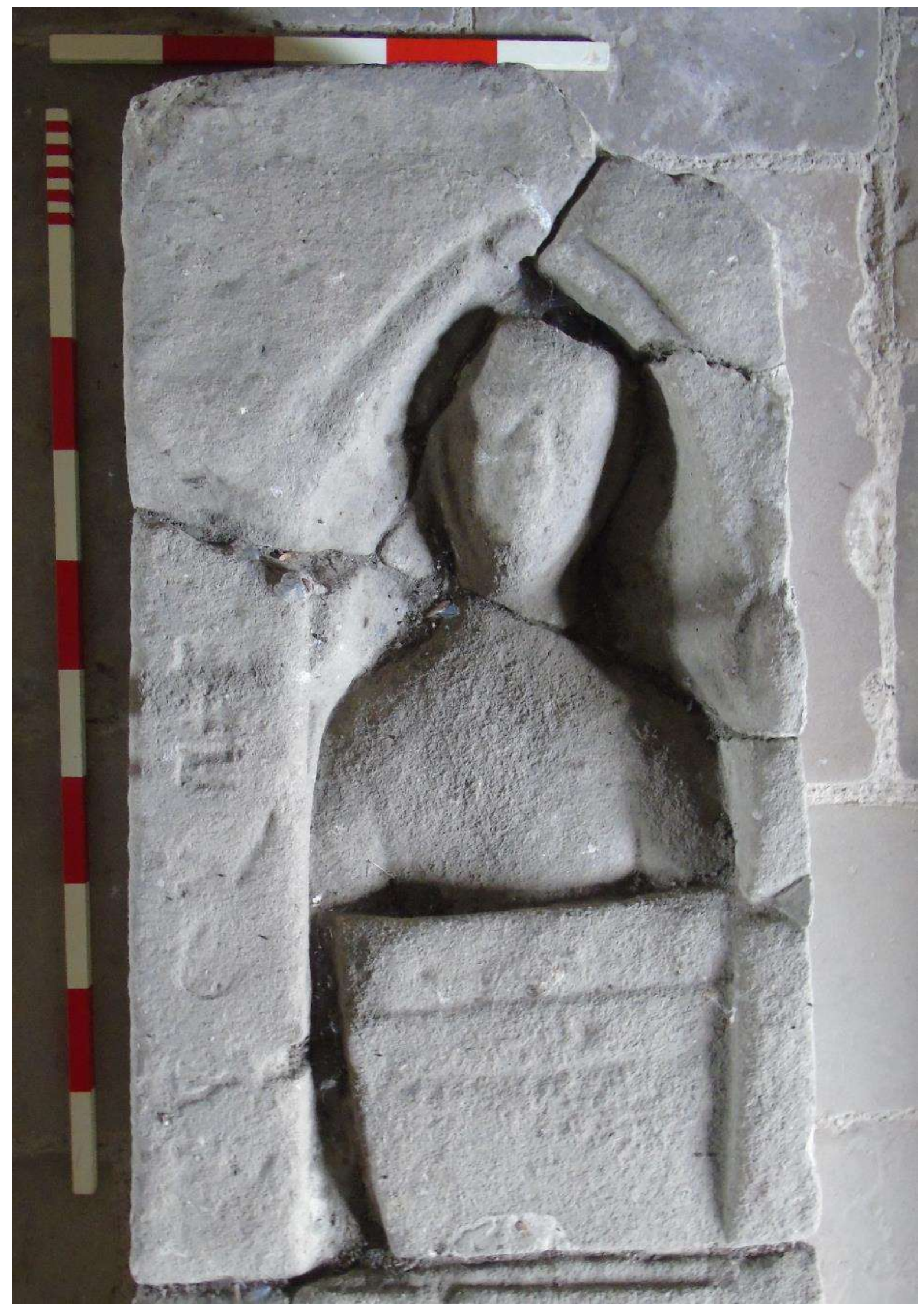

Illus. 22 Knightly semi-effigy from Valle Crucis Abbey, Gresham 175 (Gresham 1968, 186-88). (Photograph: Howard Williams) 

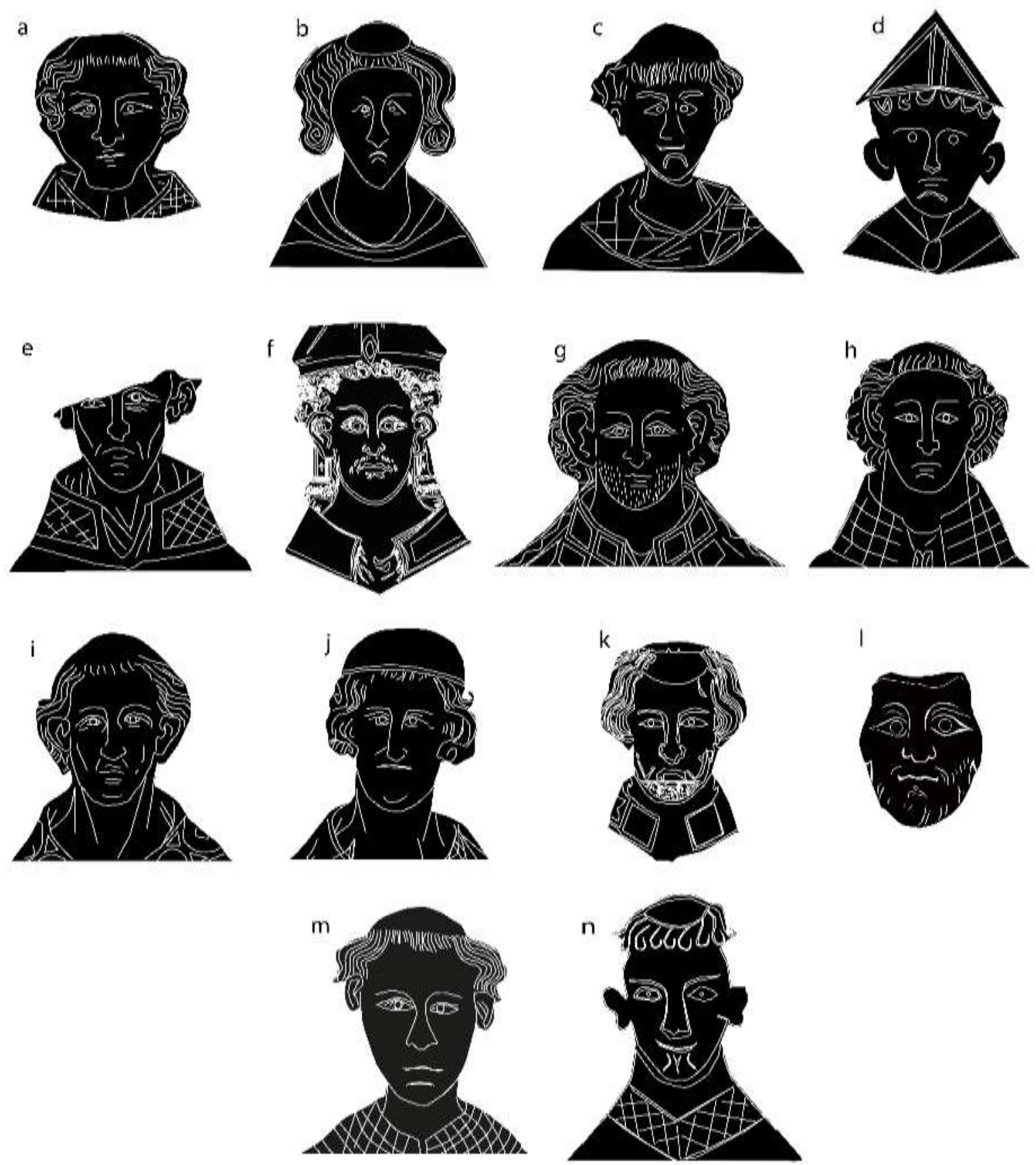

Illus. 23 Composite of figural parallels for ecclesiastical effigies of the very late thirteenth and early/mid-fourteenth century, including examples from incised slabs, brasses and tile. Effigies a-k are ordered in broad chronological order, while I, $\mathrm{m}$ and $\mathrm{n}$ are not securely dated: (a) Ashford-style brass from c. 1282 (redrawn by the author after Badham and Norris 1993, 152; (b) incised slab from Dunstable (Beds.), c. 1284 (redrawn by the author after Badham and Norris 1993, 124); (c) incised slab from Pyrton (Oxon), c. 1280-89 (redrawn by the author after Badham and Norris 1993, 120); (d) incised slab of Archbishop William de Freney, Rhuddlan, c. 1290 (redrawn by author from a photograph); (e) incised slab from Rothwell (Northants.), d. 1309 (redrawn by the author after

Badham and Norris 1993, 80); (f) detail of face of effigy of William de Greenfield, c. 1315 (redrawn by the author from Rogers 1987, 18); (g) Merton College, Oxford, d. 1322 (redrawn by the author after Badham and Norris 1993, 55); (h) incised slab from Barking Essex d. 1328 (redrawn by the author after Badham and Norris 1993 55); (i) brass from Higham Ferrers (Northants) dated to C. 1337 (redrawn by the author after Binksi 1987, 107); (j) brass from Great Brington (Northants) dated to c. 1340 (redrawn by the author after Binski 1987, 107); (k) brass (now lost) from St Non's chapel, St Davids (redrawn by author after Lewis 1974, 34-35); (I) life-sized face-shaped floor tile from Warden Abbey (Beds.); fourteenth century (redrawn by author after Baker 1993, 363): (m) the Curry Rivel priest's grave (redrawn by the author from a photograph by Brian and Moira Gittos); ( $n$ ) the 'Smiling Abbot' (drawn by the author from a photograph by the author) 
The broad ears and facial features are certainly not out of place in the repertoire of late thirteenth and early fourteenth-century effigial figures on brasses and inscribed slabs (e.g. Badham and Norris 1999, 53-5, 72, 86-9; 124; Binski 1987, 107, 117; Blair 1987, 148; Sargent 2008; Saul 2009, 73-76; 202). Indeed, a close parallel in representation of the facial features can be found with the closely dated priest's inscribed effigial slab, found in situ over his grave during recent excavations at Thornton Abbey (Lincs.). This grave has been dated by its inscription and attributed to a specific priest, Richard Wispeton, who died on 13 April 1317. The style and character of the simple features of the effigy are strikingly similar to the stone under consideration (Wilmott and Townend 2017). Another very close parallel is a recently discovered and undated priest's effigial slab from Curry Rivel (Gittos and Gittos, pers. comm. 2016: Illus. 23m).

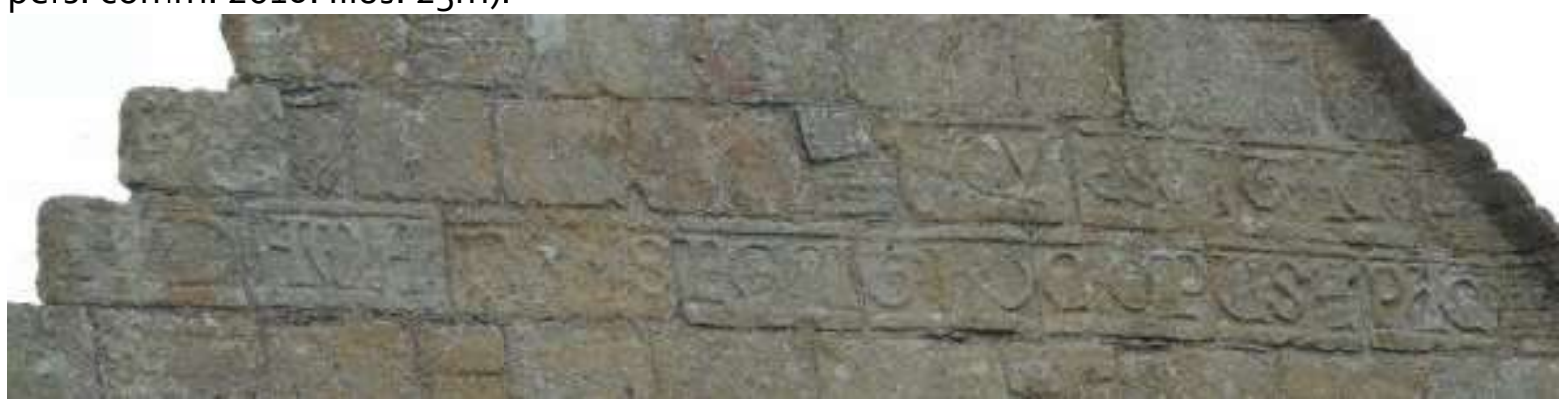

Illus. 24 The inscription on the west front of Valle Crucis Abbey, commemorating its construction by Abbot Adam (c. 1330-44). (Photograph: Howard Williams)

A specific Cistercian precedent for the image can also be identified. Full-length abbatial representations on effigial slabs are cited by Butler (1993) for the Cistercianhouses of Fountains (North Yorkshire) (to abbots who died c. 1338 and ?1346) and three slabs from Meaux (East Yorkshire). Another close parallel exists with the effigial representation of Abbot Richard de Maners (d. 1309) from Bindon Abbey, Dorset, which like the de Freney monument from Rhuddlan has a full-surround Lombardic text. There is also the Cistercian cellarer's monument from Dundrennan Abbey (Canmore, SC1229612). This differs in having its text carved (not false-relief) and it is an indent for a lost brass rather than an effigial carving. Looking outside Britain, there are effigial slabs commemorating Cistercian abbots elsewhere, showing that an abbatial effigial slab is not incongruous (e.g. Kratzke 2005, 304; Stock 2005, 242, 245, 249).

A further parallel requires us to shift media: fragments of a fourteenth-century tile tombcover from Warden, Bedfordshire are likely to come from the tomb of an abbot (Baker 1987, 373; 1993, 86; Illus. 23l). Presumably modelled on thirteenth-century retrospective abbatial tile tombs from Jumièges (Baker 1997, 375), the face bears some similarities to Abbot Hywel and offers a direct parallel to the figural representations of Cistercian abbots in the fourteenth century. Given that Norton Priory has a tile effigy (Brown and HowardDavis 2008, 258-59) and two other Cistercian houses - Bordesley and Whalley - have produced evidence of tile tombs (Gilchrist and Sloane 2005, 188), it remains possible that 
this medium was utilized at Valle Crucis too. Sadly no evidence for this has yet been forthcoming among the tile discovered during either the abbey clearance (Penson 1851a, 284) or controlled excavations (Butler 1976, 108-9).

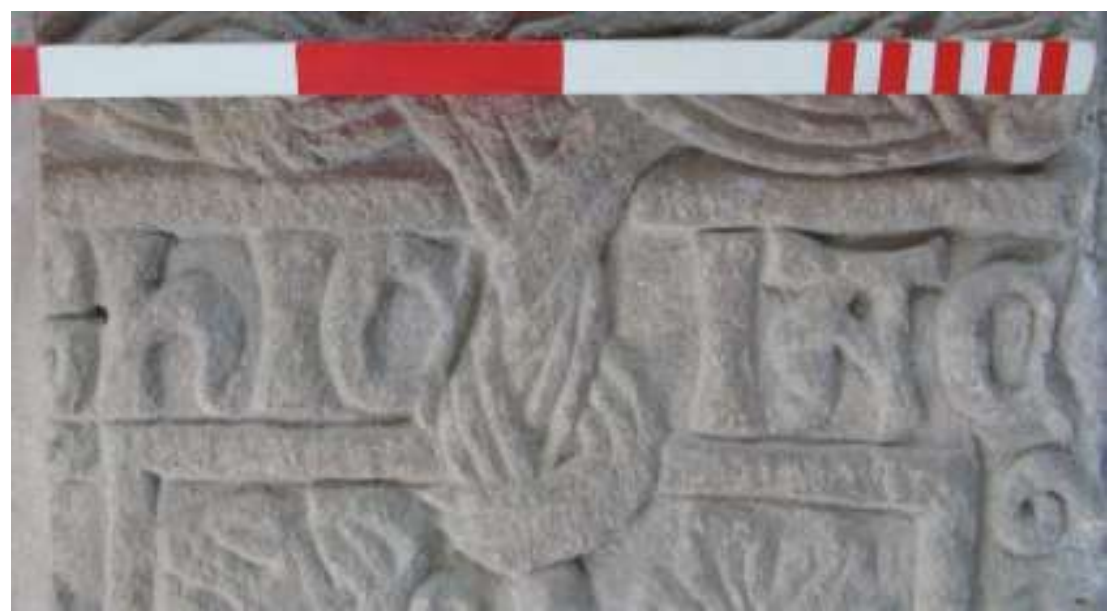

Illus. ${ }_{2}$ Close-up of the decorated grave-slab Gresham 39 from Valle Crucis Abbey, showing the $\mathrm{H}$ and $\mathrm{A}$ with parallels to the monument under investigation. (Photograph: Howard Williams)

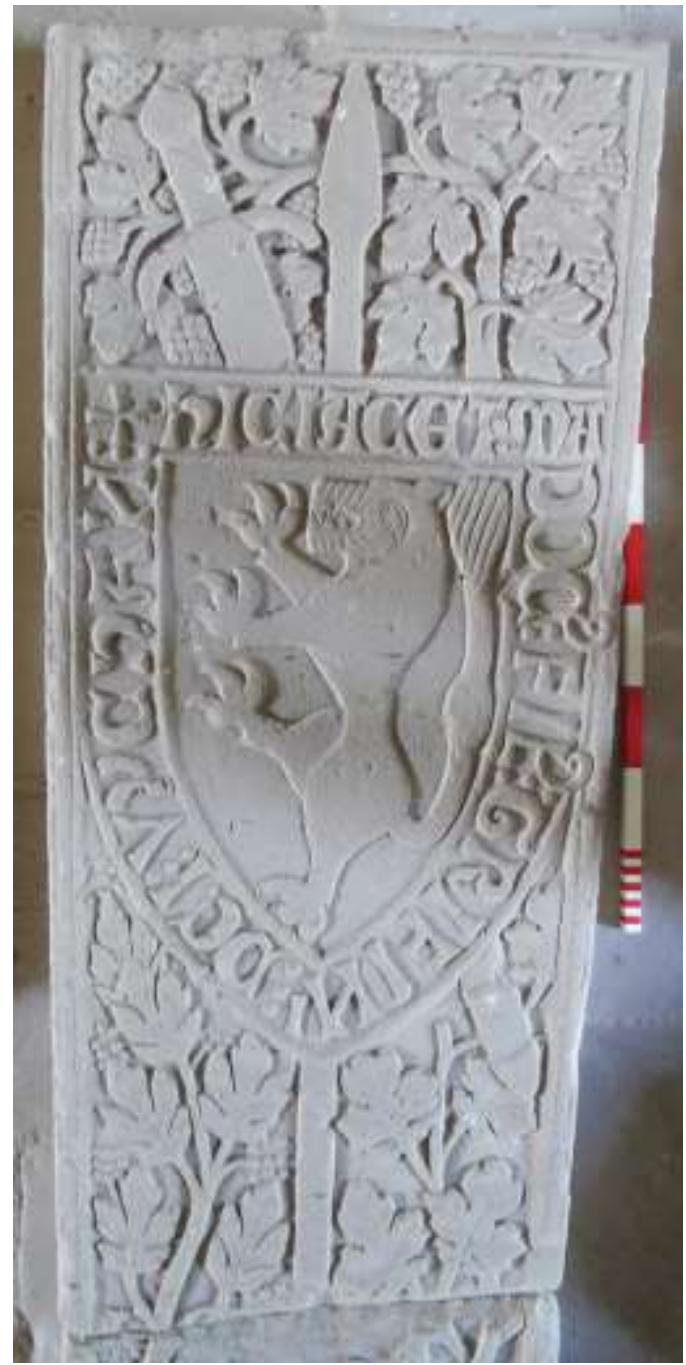

Illus. 26 The Madog ap Gryffydd Fechan heraldic slab, Gresham 122 (Gresham 1968, 137-40). (Photograph: Howard Williams) 
Drawing these strands of evidence together, despite its crude execution and distinctive appearance, in broad stylistic terms the 'Smiling Abbot' is plausible as an authentic monument. It would not be out of place to be dated to the very late thirteenth or first two decades of the fourteenth century.

\section{Parallels for the Epigraphy}

Gittos and Gittos $(2012,363)$ regard the use of Lombardic false-relief majuscules as itself a widespread and distinctive feature of their long-lasting 'North Wales school' and thus a further demonstration of the stone's authenticity as well as a crude indication of its date and provenance (see also Gresham 1968, 26-27). Indeed, the use of the text at Valle Crucis reveals its versatile deployment on commemorative stones, including upon the west front of the abbey church, commemorating its rebuilding by Abbot Adam (Illus. 24), and above the thirteenth-century carved stone head to an unknown individual - +MORUS - possibly an architectural feature from the refectory pulpit (Butler 1976, 112-13; plate VII). Together, this evidence suggests that the distinctive text was an integral part of the abbey's commemorative and architectural identity and thus deployed differently in the region from elsewhere.

There are numerous parallels with the texts and the use of three dots to punctuate the Lombardic script in the very late thirteenth- and early fourteenth-century monuments of Valle Crucis, including Gresham 29, a decorated slab to Gweirca daughter of Owain who died in 1290 (Gresham 1968, 82-84). Yet the larger, more broadly spaced letters of ABBAS (Illus 2, 3, 15 and 16) more closely resemble the slightly later decorated slab commemorating Maruruet from Valle Crucis (Gresham 39), described by Gresham (1968, 89) as 'rather clumsy' and broadly dated to the early fourteenth century (Illus. 25). Equally significant, the text contrasts in many details from late fourteenth-century monumental lettering from the region (Gresham 1968, 33).

The $A$ is regarded by Gresham $(1968,28)$ as the most varied letter in the Lombardic majuscule alphabet, and indeed, as with Gresham 40 from Llangollen, it takes different forms on the same stone (Gresham 1968, 90). The A of ABBAS is damaged on its left foot and top-right corner (Illus. 15) and the second $A$ appears similar but not fully discernible due to wear and damage (Illus. 16). Still, both demonstrably have distinctive features: (i) a straight cross-stroke which contrasts to As on most monuments in the North Wales corpus which have broken cross-bars, and (ii) a noticeable left-leaning triangle created between the cross-bar and the diagonal strokes which again contrasts with many Lombardic letter As in North Wales that sport trapezoidal or upside-down triangular spaces between the strokes.

Looking for parallels takes us to only a handful of monuments because the As on our stone do not closely resemble any of the exemplar selected by Gresham $(1968,29)$ for Lombardic letter As in false-relief. The monument's As most closely resemble those on the floriated cross commemorating Johannes son of Nicholas (Gresham 21) from Chirk, particularly the 
A in FVRAM (Gresham 1968, 77-79), a monument that might be of very late thirteenth century (according to Gresham) or early fourteenth-century date. Another parallel is with the Madog ap Gryffydd Fechan heraldic slab - Gresham 122 - discovered positioned near the High Altar in the church of Valle Crucis (Illus. 26). This stone is described by Gresham as 'perhaps the finest in North Wales' and the similarity is with the As in IACET and MADOC, but particularly in VYCHAN (Gresham 1968, 137-40; Illus 27-30). This monument is key, since a precise date of death of Madog is $A D$ 1306. The aforementioned early fourteenthcentury decorated slab Gresham 39 has an A that leans to the right but is also very similar nonetheless (Gresford 1968, 89-90). The military effigy of Madog ap Llywellyn ap Gruffydd in Gresford church, dated to c. 1330 by Gresham, also deploys a comparable A (Gresham 1968, 184-5). In summary, the A does not narrow down the dating, but it does demonstrate affinities with monuments in the vicinity to Chirk and Valle Crucis in the early fourteenth century.

An equally distinctive letter is the $\mathrm{H}$ in HOWEL, which offers wide comparisons in the 'hic iacet' formula found on many North Welsh medieval memorial stones (Illus. 26). The closest parallels are again found at Valle Crucis and nearby. The aforementioned decorated slab Gresham 29 commemorating Gweirca from Valle Crucis and dated to c. 1290 (Gresham 1968, 82-84), the decorated slab Gresham 39 commemorating Maruruet from Valle Crucis (Gresham 1968, 90: Illus. 25) and the decorated slab commemorating leuan from Llangollen (Gresham 40: Gresham 1968, 90) all offer close parallels. Moreover, Gresham 122, commemorating Madog ap Gruffydd Fechan from Valle Crucis (Gresham 1968, 138), has a slightly shortened curved stroke of the lower right of the letter similar to our stone. The latest comparable monument is the aforementioned semi-effigy to lowerth Sulien, priest, from Corwen (Gresham 164: Gresham 1968, 169-71). In addition, copper-alloy Lombardic letters $\mathrm{H}, \mathrm{C}$ and $\mathrm{E}$ were found during the 1970 excavations, 'presumably from a tomb slab with a brass inlaid border inscription' (Butler 1976, 110). The $\mathrm{H}$ was found amidst Dissolution debris in the kitchen and it is very similar in character to those mentioned above.

Yet it is a third letter - the $L$ - that clinches a close connection with Valle Crucis and again the link is with Gresham 122 (Illus. 26). The large apostrophe above and right of the $L$ finds a direct parallel in the treatment of the $C$ and $L$ on Gresham 122 (Illus. 30). For this reason, the lettering also suggests our stone might date to the last decade of the thirteenth century or first two decades of the fourteenth century and was a product of Valle Crucis Abbey's stone masons. 


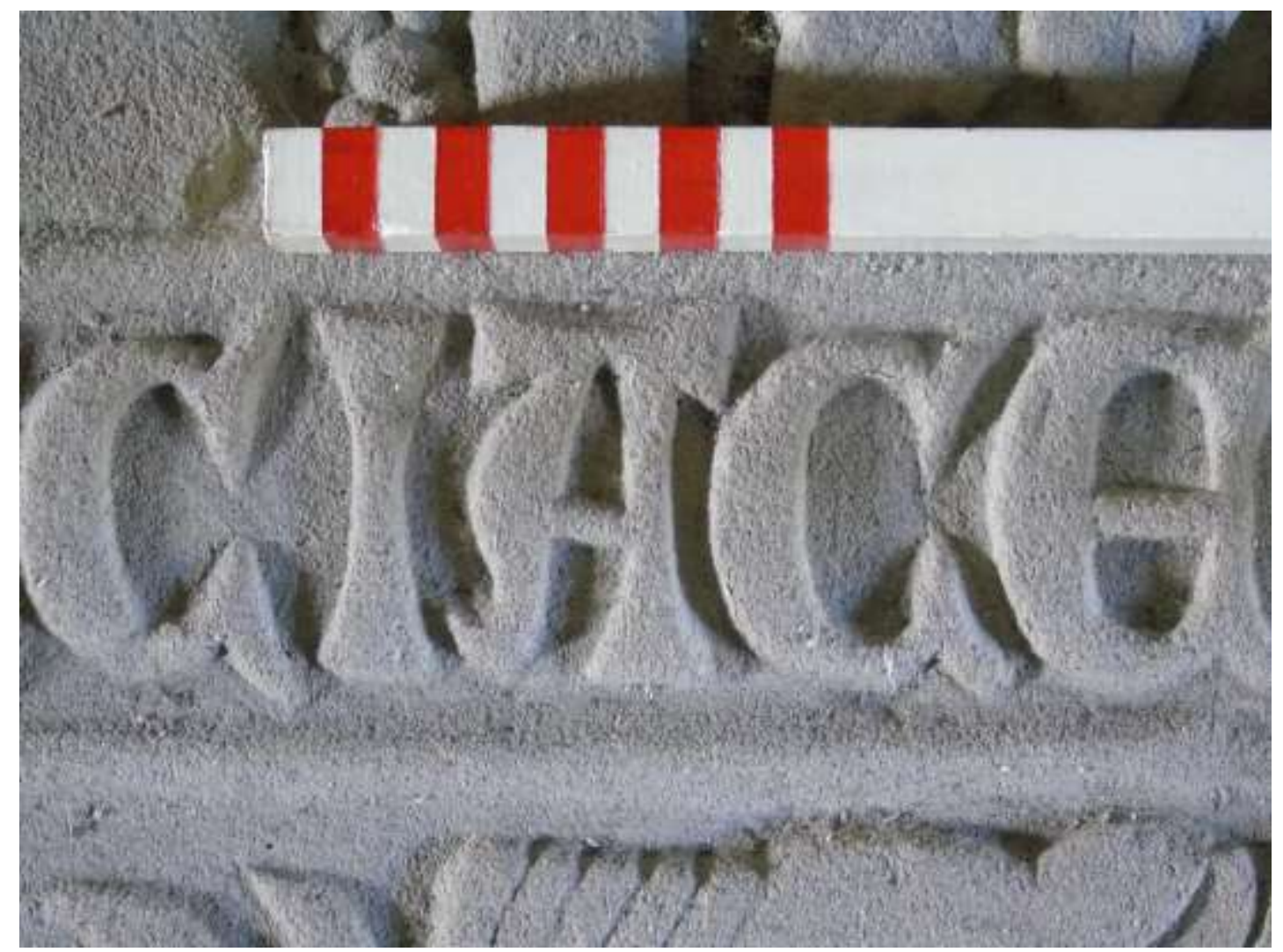

Illus. 27 Details of the letters CIACE on Gresham 122 from Valle Crucis Abbey, showing the close resemblance to the letters on the slab under discussion

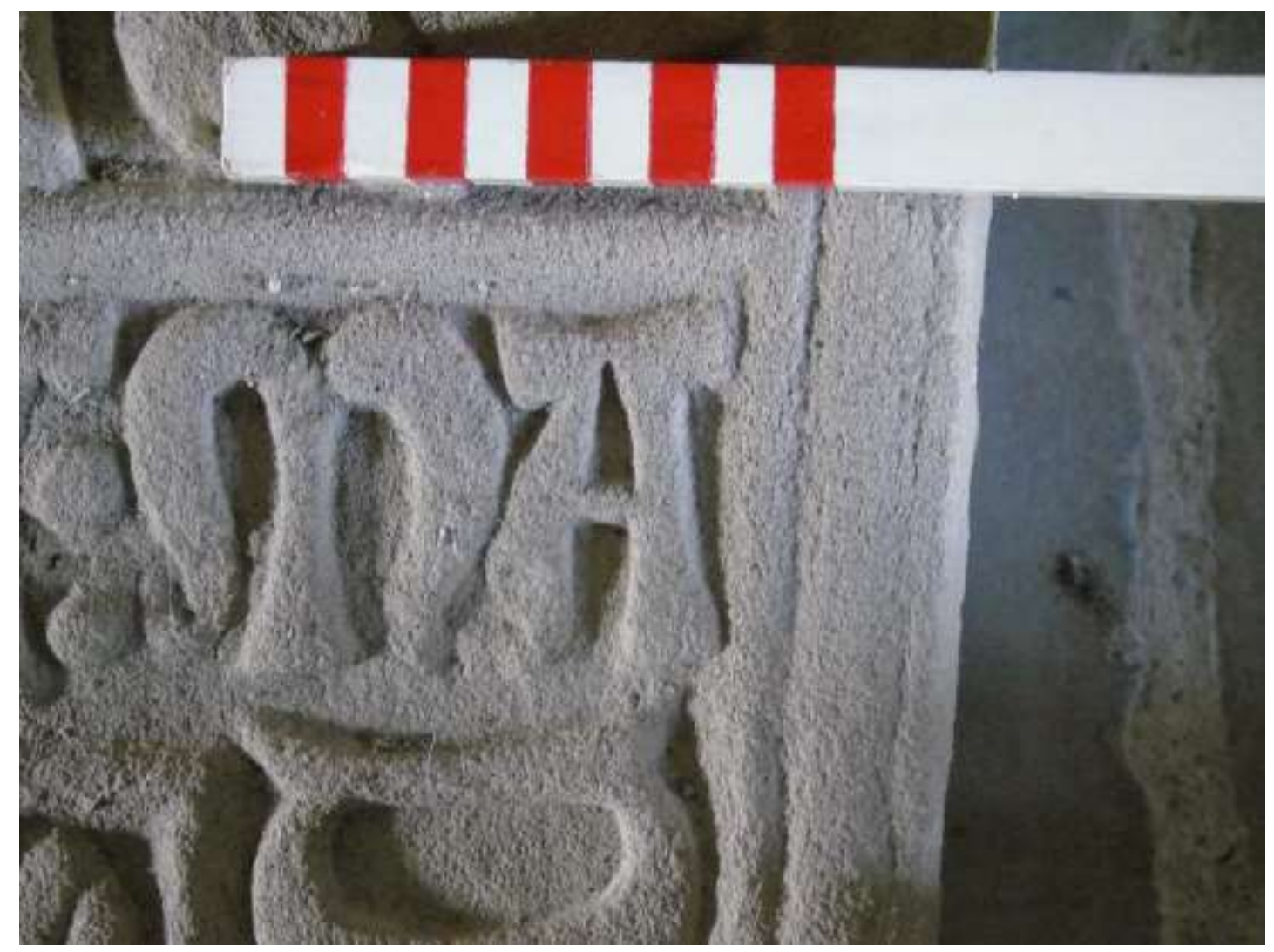

Illus. 28 Details of the letters MA on Gresham 122 from Valle Crucis Abbey, showing similarities to the letters on the slab under discussion 


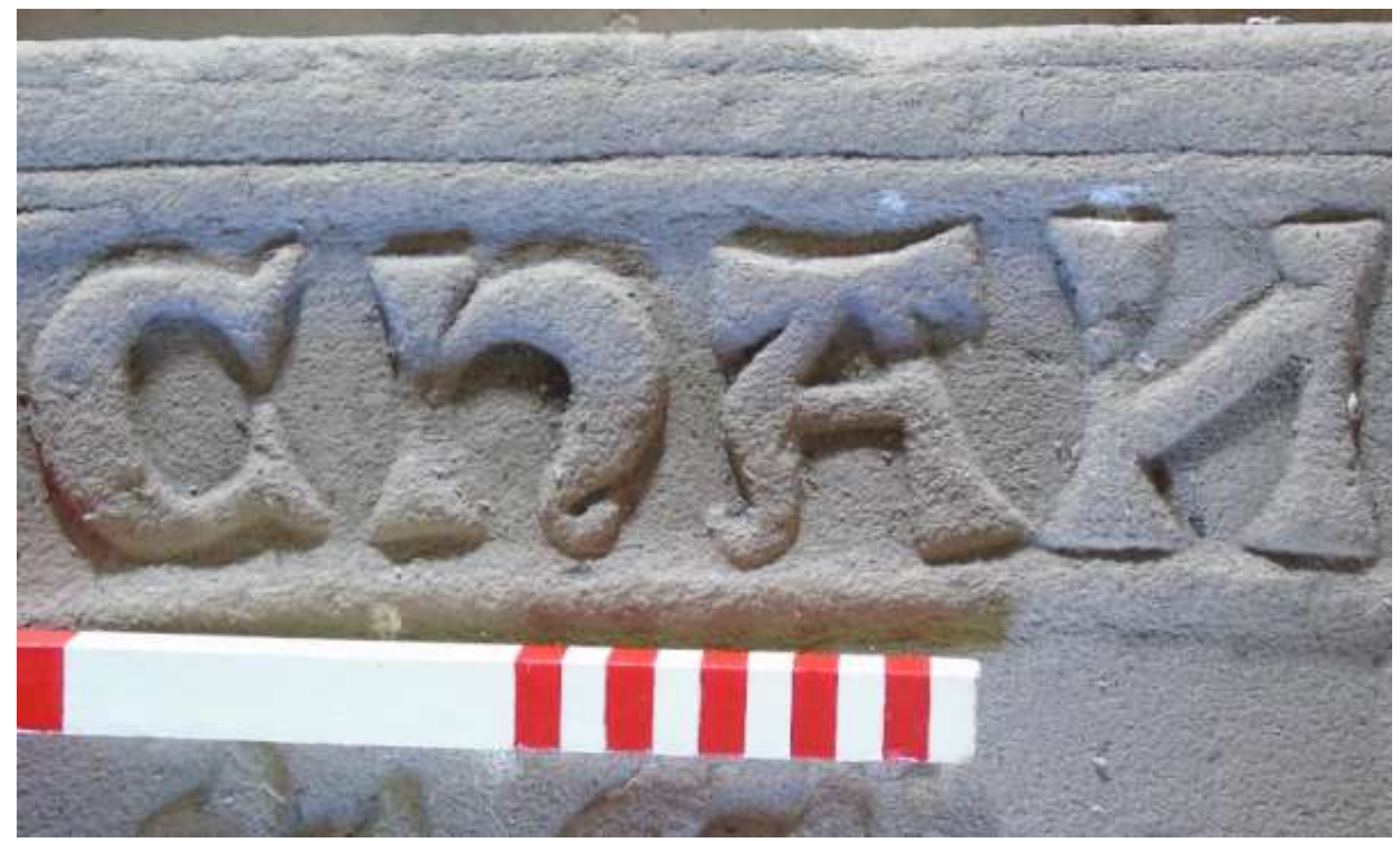

Illus. 29 Details of the letters CHAN on Gresham 122 from Valle Crucis Abbey, illustrating a clear resemblance to the letters

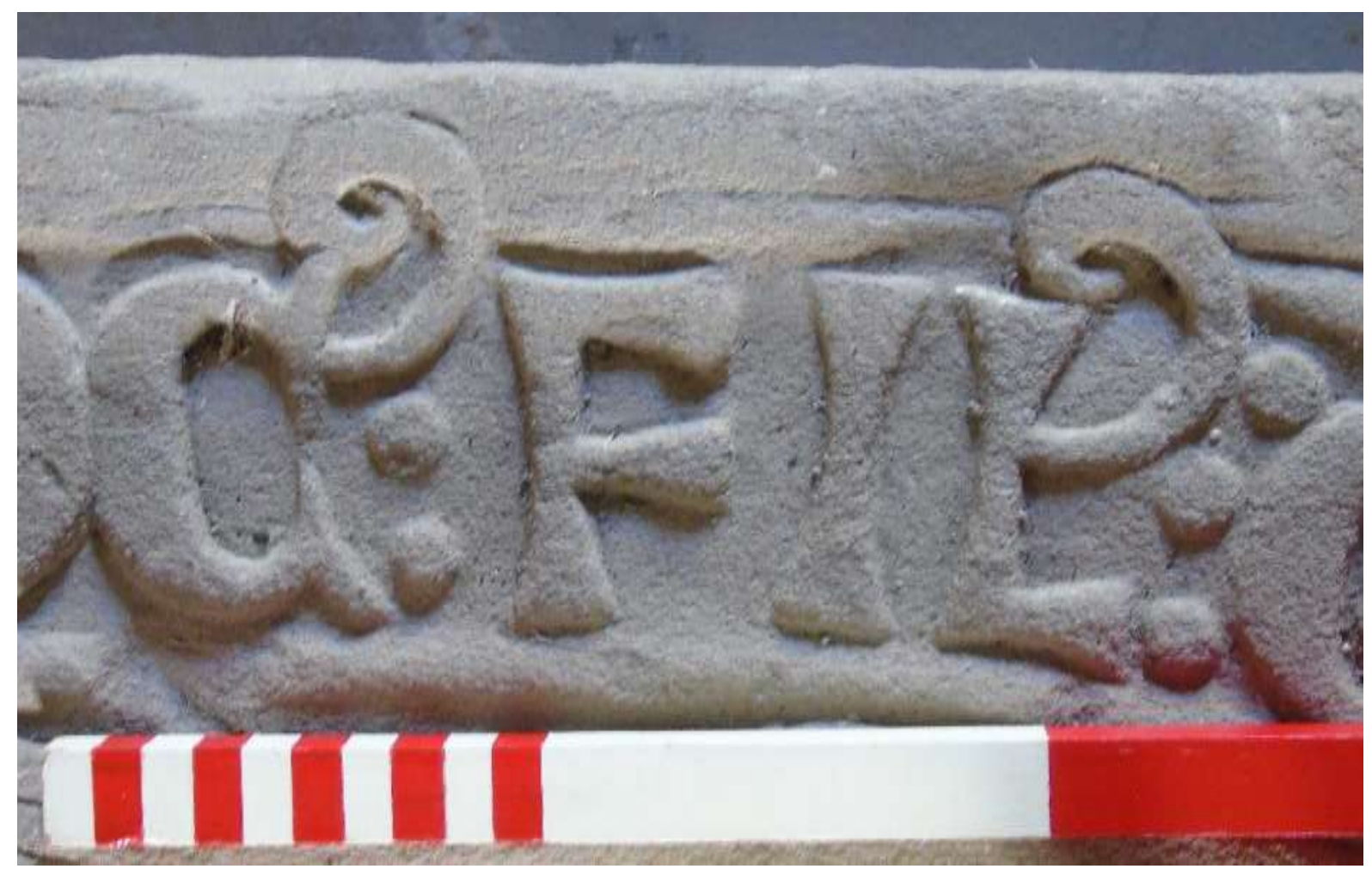

Illus. 30 Details of the letters C:FIL: on Gresham 122 from Valle Crucis Abbey, showing the close resemblance to the letters on the slab under discussion

In summary, the largest collection of medieval mortuary monuments from North Wales are known from Valle Crucis Abbey (Evans 2008, 50-51; Gresham 1968), and more still have been recently identified by Brian and Moira Gittos (Gittos and Gittos 2012). While 
unparalleled in North Wales in its figural art, the Lombardic script suggests a close link to work carved in the same tradition to those found at Valle Crucis Abbey.

\section{Identification}

Attributing medieval monuments to specific historic personages has long been a focus of antiquarian and scholarly attention, with many attributions based on flimsy or partial evidence, especially when inscribed names are either partial or lacking. For fragmented and worn monuments, this can be a challenge. For others the figural, heraldic and textual identifiers were painted on rather than carved and now lost (Badham 2011, 10).

First of all, it is important to note that, while a mitre is demonstrably absent and a crozier is inconclusive, this need not query the title ABBAS as 'abbot' for the represented figure's identity. This is because only certain abbeys were 'mitred' and depictions of non-mitred abbots without croziers are as common as those with them upon British effigial slabs (Greenhill 1976, 99).

The ER might be the end of 'frater' (Gittos and Gittos, pers. comm. 2016). For the title, the only other from North Wales is Gresham 68 from Bangor: this floriated cross-slab bears a primary inscription containing the element FRATER: IOH's: DE: LANA ES (Brother lohannes of Llanfaes) (Gresham 1968, 105-6). The monument commemorates a prior of the Dominican Friary at Llanfaes and is dated to C. 1300-1320. A later inscription on the same stone abbreviates 'frater' to FR (Gresham 1968, 106). In contrast, the aforementioned late thirteenth-century William de Freney monument from Rhuddlan uses the word 'frere' rather than the Latin 'frater' (Gresham 1968, 160-61). These examples establish that 'brother' operates in the context of monastic or ecclesiastic in a Welsh medieval mortuary context and further consolidate a date-range for the effigial slab.

If this is indeed the memorial of an abbot, we also have a script giving his name as well as his monastic identity. The name subsequently cut on the slab is clearly HOWEL. This is a name known from a number of medieval mortuary monuments from North Wales. Upon the shield of the knightly effigy from Ruabon it is spelt HOVEL (Gresham 1968, 180-82) and likewise at Tremeirchion (Gresham 1968, 224-28). However, on the Llanrwst monument to Hywel Coetmor, the name is spelt HOWEL (Gresham 1968, 205-7) and again as HOWEL both on the floriated cross from Yspyty Ifan (Gresham 1968, 214-15) and the decorated slab from Whitford (Gresham 1968, 220-22).

We can go further to narrow down the identity and date of the monument by drawing on written sources. Hywel ap Griffin of Valle Crucis is recorded around 1275 (D. Williams 2014, 204) and, whether a different person or the same one, Abbot Hywel of Valle Crucis was recorded in the 1290 (D. Williams 2001, 298; 2014, 204). In 1293, this Hywel was a witness to a quitclaim on lands in Acton (DRO DD/DY/1591). Records held at the National Archives include Correspondence of the Chancery and the Exchequer. These papers include a request in 1295 for the issue of various letters patent from Hywel, abbot of Valle Crucis, to John de Langton, chancellor (National Archives SC 1/27/174; see also Smith and London 
$2001,318)$. The dates are consistent with the style of the engraving on the stone and no other abbots with this name are known at Valle Crucis. Abbot Hywel is, significantly, last abbot before the mention of Adam who presided as abbot 1330-44 and whose name is itself inscribed in Lombardic capitals on the west front of the renovated church (D. Williams 2001, 298) (Illus. 24).

There are other possible Hywels at Welsh Cistercian monasteries, including one at Strata Marcella in 1215 recorded by D. Williams (2014, 204). The Monastic Wales website notes that a Dafydd was abbot at Strata Marcella in 1215 but that there was an abbot called 'H. . ..$'$ at Strata Marcella in 1276 (http://www.monasticwales.org/person/142).

There were abbots named Hywel at Whitland Abbey in 1352 (D. Williams 2001, 298) and at Aberconwy in 1406-9 (D. Williams 2014, 204), but the later dates and more distant locations make these less likely for identification with this monument. There may have been, of course, other abbots named Hywel that we have no knowledge of at Valle Crucis or other abbeys. Still, on the basis of the evidence at present, we appear to have a monument composed in the lifetime of Hywel, abbot of Valle Crucis, or by his successor - perhaps Abbot Adam - and brethren soon after his death.

\section{Discussion: The Effigial Slab at Valle Crucis}

It is almost certain we are dealing with an authentic fragment of a recumbent monument: one intended to be situated on the floor or within a recess in the abbey's church, chapter house or cloistral walk. While other prominent grave-slabs have been discovered at Valle Crucis (Gresham 1968; Gittos and Gittos 2012), there is no hint from archaeological excavations or architectural details as to the original position of this particular stone. Doubts and suspicions might always be raised regarding an unprovenanced, fragmented and unique carved stone monument, yet the brief 1895 report and image, the figure's features, the epigraphy, the possible commemorative formula employed, the wear and reddening of the stone, the apparent use of comparable sandstone to the monuments at Valle Crucis, all point to this being genuine medieval stone carving.

Intramural flat tombs such as this were '.. the original creation of the medieval genius and its ambivalent sensibility, the symbol of a compromise between the traditional abandonment to sanctified ground and the new need quietly to assert one's identity' (Ariès 1981, 239). Such a tomb would become an important locational mnemonic device within the monastic space (see Gilchrist and Sloane 2005, 184), facilitating a transactional relationship between the dead abbot and the monastic community (Binski 1996, 71).

The particular significance of the monument derives from its uniqueness and revealing a new dimension to a recumbent monument carved for an abbot of a major Cistercian monastic house. The Cistercians, as a reformed monastic order, were famed for the restrictions upon, and austere, mortuary monuments and church architecture (Butler 1993). Memorial slabs from the Cistercian houses of Strata Florida and Bordesley (with three from the latter discovered in situ), for example, are varied in form and ornament, but modest in 
character and without representations (Gilchrist and Sloane 2005, 185). Still, from the twelfth century onwards, and particularly with relaxed regulations on aesthetics into the fourteenth century, Cistercian monasteries became key locales for the commemoration of royalty, nobility and ecclesiastics. Tombs provided an important dimension to monasteries' socio-political and religious significance (Gajewski 2005; Jamroziak 2005, 324).

Tombs of abbots, in particular, were a medium for communities to assert and cultivate their own identities and relationships with patrons and the wider world. Moreover, a careful and conscious humility in floor-level memorials and/or relatively modest monumentality could readily be mobilized in a positive fashion to create a distinctive commemorative programme at particular institutions (cf. Binski 1996, 89-90). Written sources reveal that abbots might be buried in the monks' cemetery east of the church, in the monastic church near their stall or the high altar, in the chapter house where his authority in life was performed (Butler 1993, 78-79), or perhaps also in the east cloister alley (Gajewski 2005, 7375). Up to c. 1300 , Cistercian abbatial monuments might be still unmarked slabs, with the occasional use of sculpted croziers, sometimes held by disembodied hands and sometimes with crosses. Given this commemorative restraint (Butler 1993, 84), Cistercian abbatial effigies and chest tombs are exceptional and late in date (e.g. Carter 2012: 44-45), although there are striking exceptions, such as the thirteenth-century effigy of an abbot from Dundrennan Abbey (Coppack et al. 1999, 105; https://canmore.org.uk/collection/ 1229611). In Wales, there is an undated and worn fragment of a possible abbatial effigy from Tintern, and the very worn effigy of Adam of Carmarthen at Neath Abbey (Cowley 2005). Yet no comparable effigial slabs survive from other Welsh Cistercian houses.

For Valle Crucis, none of the medieval memorials previously identified have monastic, let alone abbatial, commemorative subjects. Therefore, Valle Crucis (as with other Cistercian houses in Wales founded by Whitland) has been recognized as a focus of secular patronage, burial and commemoration by Welsh royalty and lords (Pryce 2005, 85). For Valle Crucis this is materially evidenced in the surviving fragments of graveslabs and historical evidence that this was the burial place of the founder Madog ap Gruffudd Maelor and his sons (Gray 2005,17 ; Pryce 2005,85 ). Yet the role of abbatial burial and commemoration in these communities has received no attention. The grave cover fragment is the first evidence of an abbatial dimension to the commemorative strategy of the monastic house (Butler 1993, 85). As such, it seems to also be the only known effigial slab to a Cistercian abbot from Wales and perhaps the first named memorial representation of a Cistercian abbot from Britain.

The abbots of Valle Crucis were key figures in the economy, politics and religious life of North Wales. The abbey became the primary burial place of its founder and other members of his dynasty. Abbot Hywel was likely a highly influential figure in Welsh religious and political life, and was commemorated at a challenging and tumultuous time in the abbey's history. Valle Crucis was subject to damage during Edward's 1282-83 campaign in Wales, despite a letter of protection (D. Williams 2001, 36). In 1283 and 1284, Valle Crucis received compensation from the English crown for damage to its buildings, lands and impropriated 
churches (D. Williams 2001, 36-37, 39). Marcher lords, like Roger Mortimer of Chirk, appropriated lands from the abbey in 1305 (D. Williams 2001, 38). Like other Cistercian houses, Valle Crucis was in a frontier zone and thus 'trapped by [its] own history' of endowment and support from Welsh

families (Gray 2005, 18).

Despite these disruptions during the time of Abbot Hywel, the abbey seems to have been prosperous into the early fourteenth century and persisted in attracting the patronage and burial of local nobility and thus remained a socio-political, economic as well as religious hub. King Edward held the abbot of Valle Crucis in 'special confidence' in 1294 and visited Valle Crucis in 1295. The abbot (presumably Hywel) stayed in Wales in 1298 rather than attend the General Chapter in France on the king's business (D. Williams 2001, 40: Evans $2008,8-12$ ). It was a possible core production site for funerary monuments, with the chronological focus of carving in the early fourteenth century (Gittos and Gittos 2012).

Certainly, the distinctive combination of false relief Lombardic lettering and an inscribed effigy has no parallel in the North Wales corpus with the closest parallel being the aforementioned William de Freney monument at Rhuddlan dated by Gresham $(1968,161)$ to around 1290 . Similarly, there are no immediate parallels from South Wales known to the authors (M. Gray pers. comm.). The extensive, if by no means exhaustive, European survey by Greenhill (1976) reveals no precise parallels either, although Cistercian abbatial effigial slabs are known (see above). We would like to highlight two dimensions to its significance here: its importance as part of a cumulative assemblage of tombs at Valle Crucis in the early fourteenth century, and the power of the image itself on those engaging with it through its gaze and smile.

There is one precedent among the existing known funerary monument from Valle Crucis. As well as many with a comparable Lombardic script, there is also a semi-effigial monument of the early fourteenth century to leuaf ab Adda (Gresham 175: Gresham 1968, 186; Illus. 20). There is also the sculpted bearded head with a commemorative Lombardic text ('Morus') found in the refectory (Butler 1976; see above). Amidst the Valle Crucis assemblage, it is clear that tombs honoured both lay patrons and abbots of the house, and the Lombardic text was a theme that connected many of them. Indeed, this 'community of the dead', spanning the church and chapter house, might have been one of the key dimensions to the material constitution and expression of the community's identity and prestige (H. Williams 2003). Yet simultaneously, the memorial depicting Abbot Hywel would have stood out from the others in its deployment of the abbot's form, so that, wherever it was installed in the abbey, it would have undoubtedly held a special and striking significance as a mortuary monument. Indeed, we might even suppose that the monument was raised immediately prior to the rebuilding of the abbey by Abbot Adam, who oversaw the construction of the west end of the church following a fire. The reddening of the stone might be the traces of a fire affecting the abbey church or cloistral range, one of several evidenced from archaeological evidence at Valle Crucis (Butler 1976). 
In summary, the secular patronage of Cistercian monastic communities resulted in lay funerary monuments, and to date the assemblage of stones from Valle Crucis has been largely regarded in this light. However, the monument reveals the distinctive role of effigies as a mechanism for the community to identify and commemorate their own brethren, at least abbots held in particular esteem and/or with a distinctive place in the history of the community.

The power of the image: the gaze

Understanding the abbot's effigial slab requires us to consider the importance of the senses on commemorative art and visuality as part of mnemonic strategies within specific religious spaces (Giles 2007). We obviously lack knowledge as to the slab's original location. Still, positioned to cover the grave, thus close to the earth, and presumably within the cloister or church of Valle Crucis and thus beside space traversed by the monastic community (whether on the floor or in a chapel or recess), the monument would have facilitated and enhanced the continued use of the space for liturgical purposes and allowed the kinetic, haptic and visual actions of living monks to interact (and thus interact and intercede through prayer) with the tomb of their former abbot (see Astill and Wright 1993; $\mathrm{H}$. Williams 2003). Yet how would the particular deployment of an effigial slab, especially a smiling one, have operated within a Cistercian commemorative context?

Images had an agency to affect memory in the medieval monastic context through their gaze being perceived to create a two-way interaction with living subjects (see Graves 2007, 516). As Ariès (1989, 241) cogently stated, in contrast to later closed-eyed effigies, twelfthand thirteenth-century '. . . recumbent figures are neither dead men nor living men whose portraits were desired. They are identifiable, of course, but no longer as men of the earth. They are beati, blessed beings, glorified bodies, eternally young. ..' This ambivalent position between living person and dead corpse, between body and soul, can be regarded as a common strand in the idealization of selfhood created by medieval effigies (Binski 1996, 93-94; Badham and Oosterwijk 2015, 89). Moreover, this is relevant as much to the representations of abbots as any other mortuary subject. It most certainly extends to our likely early fourteenth-century fragmented slab under discussion, where the simplified features, while perhaps too readily dismissed as evidence of crude execution, also serve to imply youthfulness and an arresting of corporeal decay (cf. Binski 1996, 71). The abbot's mortuary representation thus allows consideration of the situated agency of the image in relation to these broader medieval trends and concepts (see Graves 2007, 517), since the image might have served to foster ocular interaction with the monastic community. If so, we might speculate that such distinctive funerary representations had a strong mnemonic and emotive role, by binding together the community's past and present, life and death, as well as recalling the dead individual's selfhood, deeds and legacy, and articulating their aspired afterlife destination.

The gaze was perhaps a key aspect of the dynamic interaction set up by funerary images, both negotiating ongoing dialogues between the living and the dead and articulating the deceased's selfhood (Binski 1996, 99-100). For example, Archbishop Walter De Gray's tomb in York, dating after AD 1255, originally had a painted coffin lid that Sillence (2005) 
has argued was originally intended as the principal top of the tomb rather than a temporary feature awaiting the complete Purbeck effigy. This example also reminds us that effigies were present in many media across thirteenth-century Europe, including tile, mosaic and enamel (Sillence 2005, 7). This context raises the possibility that the slightly later effigial slab of Abbot Hywel's might be readily polychrome when installed at Valle Crucis (Gresham $1968,43)$.

Therefore, the gaze of the medieval effigy - sculpted or engraved - was not passive, but intended to be active: impacting on those viewing it and provoking them to devotion, prayer and thus remembrance. The figure was, moreover, not only interacting with the living, but with the architectural space itself. Sillence $(2005,9)$, for example, discusses how the painted coffin lid of Walter De Gray would have originally been in interaction with the figure of the Archangel Michael upon the vault above his grave: the image's line-of-sight was important. In the context of the church or chapter house of Valle Crucis, the expression of the effigial slab as a 'seeing' representation, but also (especially in the light of the exaggerated ears and nose) as a 'listening' and 'smelling' abbatial image, might have been significant. The monument became a polychrome, sensorial, and sensing presence, able to receive the prayers of the attendant monks, easing the abbot's journey to heavenly Salvation. In short, we must question whether this commemorative image also took on a devotional role in the monastic space. Especially given the rarity of effigial representations in the Cistercian context, the effigial slab would likely have become a tangible locus for prayer and memory within the abbey's ongoing dialogues between the living monastics and visitors, and the memory of its former abbot (cf. Gilchrist and Sloane 2005, 194). In this regard, the 'likeness' of the figure to the deceased, and his gaze, especially if originally painted, might have been together more active and significant than is sometimes accepted for monuments before the fifteenth century (contra Binski 1996, 103; see Badham and Osterwijk 2015, 89). Especially in the context of a monastic order that practiced considerable constraint in its deployment of devotional figural art (e.g. Graves 2017, 52024 ), the grave slab might be considered a distinctive and especially powerful for forging monastic memories.

\section{A smile for the living or a smile for the afterlife?}

While we accept that inferring expressions is subjective, it is striking how such a key dimension as the smile is typically omitted from discussions of later medieval funerary monuments, and indeed devotional images more broadly (cf. Marks 2004). Where they occur, much more commonly among laity, effigial representations of the medieval dead almost universally depict either neutral or sombre facial expressions, with the lips pursed into a straight line or down-turned. Smiling effigies do occur, however. For example, among the 'Ingleby Arncliffe group' from North Yorkshire, at least four - the two military effigies from Ingleby Arncliffe and the ladies from Kirkleatham and Appleton-le-Street have pursed modest smiles (Gittos and Gittos 2002). However, these expressions seem to receive no comment by scholars. In North Wales, there are two effigies that have escaped damage sufficient to make out smiling, as opposed to the farmore common neutral or dour, expressions. Gresham's $(1968,172)$ published drawing of a lady's effigial slab from Caerwys 
(Flintshire) shows no expression, but first-hand examination of the stone reveals she is smiling. Meanwhile, the aforementioned fragmented male civilian effigy from Overton (Wrexham) has a lopsided smile (Gittos and Gittos 2012, 382). Other effigies across Ireland, Scotland, England and Wales may indeed depict smiles, but not only does later damage obscure such features, the systematic identification, the detailed recording and investigation of facial features and expressions is currently lacking.

Among the effigial slabs reported by Greenhill (1976), there are only very few, disparate and demonstrably smiling figures. Sir Bjørn Finssøn from Trondheim Cathedral, depicted in martial attire bearing weapons, is a seemingly unique late-thirteenth-century example (Greenhill 1976, plate 6ob). Philippe de Sai from Bescançon, Doubs, France, a knightly effigy of 1359, has a modest smile too (Greenhill 1976, plate 61b). Much later is a civilian from Lingfield, Surrey, dated to c. 1530 (Greenhill 1976, plate 124b). Among clergy, the only modestly happy-faced cleric is Gherard von Lynden from Nossendorf, Germany, and dating to $1364 ;$ he was 'murdered at the altar in time of Mass' and he is surrounded by depictions of his murderers (Greenhill 1976, 163; plate 18a).

Turning to brasses, a straight or downward-turned mouth is near ubiquitous (e.g. Badham 2009), including the earliest known English brass from Ashford, Kent, which bears (in broad terms) a resemblance to the 'Smiling Abbot' in appearance (Badham 2009, 12). The same dour expressions populate Europe's metal effigial tombs (Badham and Oosterwijk 2015). Still, there are rare exceptions in metal. Among Norris's sample of brasses, a female effigial representation with a grin comes from Sedgefield (Durham) (Norris 1977, 314, plate 12), dating to around 1320. Also, Norris (1977, plate 206) depicts the brass of George Townsend, c. 1504 , of East Rainham, with a subtle smile. Badham $(2009,18)$ illustrates a lady and knight, possibly of the Lacon family, dated to the late fifteenth century, with distinctive smiles. Likewise John Moore's memorial, dated to 1532, has up-turned lips. In this case, the text emitting from his hands rises to a depiction of the Lord in Majesty (Norris 1977, plate 240). The Coventry series 1 brasses of the late fifteenth century also feature broad smiles (Badham, pers. comm. 2016). Later effigial brasses show corpses whose emaciated appearance necessarily creates a cadaverous grin, but this represents a very different association for the expression (e.g. Norris 1977, plate 249; Badham 2009, 47).

Tile is a further potential medium for discussion when considering Cistercian commemoration. Here, aforementioned the fourteenth-century tile face-shaped floor tile from the Cistercian house at Warden - one of the order's more senior foundations in England - offers a possible parallel. This bearded facemight be part of a tile effigial floor retrospectively commemorating the first abbot of the monastery - Simon - up to a century after his death (Baker 1993, 59; Illus. 23l). Baker subjectively regards the image as showing a 'humorous face with lively intelligent eyes and a gentle smile' (Baker 1987, 373). However, we concede that the corners of the mouth are only ever-so-slightly upturned, hence this is extremely ambiguous and offers no direct parallel with the strikingly lunate-mouthed inscribed figure. 
It is important to remember that we have lost evidence of so many medieval monastic memorial stones, brasses and tiles, therefore many further examples with similar expressions might have once been created in the medieval period. In particular, ecclesiastical brasses might have been a medium in which further examples once existed yet they have rarely survived compared to military and civil ones, and none survive intact of male monastics from England before the fifteenth century (Norris 1977: 14; 21; 87). Issues of survival aside, there is nothing in this brief review to suggest an abbot's smile was commonly depicted in mortuary art and certainly not in Wales. Notwithstanding their rarity, these disparate examples might hint at a possible, occasional and idiosyncratic, depiction of smiling memorial figures.

Hence, we are led to wonder about how this distinctive facial expression, together with the rarity of figural representation, would have operated to set this memorial apart within the context of Cistercian mortuary commemoration at Valle Crucis.Moreover, was the smile in this context a positive expression of achieved Salvation, and/or a sign of benevolence towards the community over whom the abbot presided in life? Were the community intended to regularly interactwith this figure's gaze during church services?

Alternatively, were the monks expected to recognize the deceased abbot's happy gaze upwards towards Heaven as it expresses confidence or assurance that the dead abbot's soul was able to apprehend the heavenly realm? It might be related to an economy of expression in which the smile denotes both body beneath and soul rising from resurrection (I owe this point to Dr David Harry). The smile is certainly emotive, memorable and perhaps idiosyncratic, honouring the dead for his rank and his personal history, an influential religious and political figure who presided over the monastic house at a time of disruption and turmoil.

\section{Conclusion}

Neglected in comparison to English church monuments, recent work has revived interest and understanding for Welsh medieval memorials (e.g. Badham 1999; Biebrach 2010). Meanwhile, a recent reappraisal of stones from North Wales serves to both revise and extend Gresham's (1968) interpretation of a distinctive 'workshop', at least in part based on Valle Crucis (Gittos and Gittos 2012; see also Badham 2010, 28). This newly rediscovered fragment of trapezoidal effigial slab, seemingly commemorating an abbot of Valle Crucis, significantly enhances our appreciation of the abbey's commemorative repertoire, especially given that none of the previously recovered memorial stones are conclusively commemorating monastics, let alone abbots. Moreover, it provides a case study revealing how 'lost' and rediscoveredfragmentary monuments can reveal anew aspects about a medieval monastic community and their relationship with the dead.

This article proposes that the most likely interpretation is that the 'Smiling Abbot' is the effigial slab of one of the abbots of Valle Crucis, a predecessor of Abbot Adam who oversaw the rebuilding of the abbey church of Valle Crucis in the 1330s/40s. It remains unclear for how long Hywel (Howel) was abbot, when precisely he died after his brief mention in the written sources, and when this monument was carved and installed to his memory. 
However, scrutiny of the monument suggests it most likely dates from the very end of the thirteenth century or the first two decades of the fourteenth century. This was the time of Valle Crucis's apogee as a monastic institution and focus for mortuary commemoration. The abbot is depicted in an idiosyncratic fashion, fully aware and awake, perhaps confident in hopes of Salvation and tangible for those encountering, and perhaps walking past, his tomb within the monastic complex. Holding a book and paten is a seemingly rare, if not unique, combination of items, making these tomb especially memorable. The precise hair style is also unique in the repertoire of effigial slabs and brasses. His memory was also promoted to those engaging with the monument by emphasizing the performance of his abbatial duties, his gaze and his smile. In this way, this relatively modest monument was integrated into the fabric of the monastery as a site of memory (see also H. Williams 2003). The 'Smiling Abbot' might have been a long-term locus in the commemorative topography of Valle Crucis, signifying and asserting the monastery's history, identity, prestige and wealth.

\section{Acknowledgements}

Howard Williams researched and wrote the text with input from, and the 'Provenance' section written by, David Crane. Gillian Smith liaised with the owners for the stone's display and facilitated the research and writing of the article. Aaron Watson produced high-quality photographs of the 'Smiling Abbot' stone and made invaluable additional observations about the monument.

We would like to thank Meryl and Jerry Butler for permission to write about the memorial which in many ways confirms their existing research into the monument. The authors would like to thank the article's two anonymous referees as well as Sally Badham, Cynthia Burek, Brian and Moira Gittos, Carly McEvoy, Madeline Gray, Mark Hall, David Harry, Andrew Haycock, Patricia Murrieta-Flores, Ruth Nugent, Sophie Oosterwijk, Bob Silvester, Karen Stöber and Hugh Wilmott, for assistance and helpful suggestions during the preparation of this article. Thanks especially to Brian and Moira Gittos for permission to reproduce their image of the Corwen monument (Illus. 20).

Work on this article benefited from financial support following Howard Williams receiving the University of Chester's Faculty of Humanities Teaching Innovation Award for 2016.

\section{Supplemental Material}

The online supplemental file can be accessed at https://doi.org/10.1080/00665983.2017.1366705, containing a photogrammetric model of the 'Smiling Abbot' grave-slab fragment by Aaron Watson.

\section{Bibliography}

ARIĖS, P. 1981. The Hour of Our Death, New York: Knopf

ASTILL, G. and WRIGHT, S. 1993. Perceiving patronage in the archaeological record: Bordesley Abbey, In M. Carver (ed.) In Search of Cult, 125-37, Woodbridge: Boydell 
BADHAM, S. 1999. Medieval minor effigial monuments in West and South Wales, Church Monuments, XIV, 5-34

BADHAM, S. 2011. Medieval Church and Churchyard Monuments, Oxford: Shire

BADHAM, S. AND NORRIS, M. 1999. Early Incised Slabs and Brasses from the London Marblers, Reports of the Research Committee of the Society of Antiquaries of London, 6o, London: Society of Antiquaries of London

BADHAM, S. AND OOSTERWIJK, S. 2015. 'Monumentum aere perennius'? Precious-metal effigial tomb monuments in Europe 1080-1430, Church Monuments, XXX, 7-105

BADHAM, S. 2010. What constituted a 'workshop' and how did workshops operate? Some problems and questions, in S. Badham and S. Oosterwijk (eds) Monumental Industry: the Production of Tomb Monuments in England and Wales in the Long Fourteenth Century, 1236, Donington: Shaun Tyas

BADHAM, S. WITH STUCHFIELD, M. 2009. Monumental Brasses, Princes Risborough: Shire

BAKER, E. 1987. Images, ceramic floors and Warden Abbey, World Archaeol., 18(3), 363-81

BAKER, E. 1993. The Warden Abbey pavements: fine art on the floor, in M. P. Lillich (eds) Studies in Cistercian Art and Architecture, Cistercian Studies Series, 134, 59-77, Kalamazoo, MI: Cistercian Publications

BIEBRACH, R. 2010. Effigial monuments in fourteenth-century Glamorgan: patronage, production and plague, in S. Badham And S. Oosterwijk (eds) Monumental Industry: The Production of Tomb Monuments in England and Wales in the Long Fourteenth Century, 114-36, Donington: Shaun Tyas

BINSKI, P. 1996. Medieval Death: Ritual and Representation, London: British Museum Press

BINSKI, P. 1987. The stylistic sequence of London figure brasses, in J. Coales (ed.) The Earliest English Brasses: Patronage, Style and Workshops 1270-1350, 69-132, London: Monumental Brass Society

BLAIR, J. 1987. English monumental brasses before 1350: types, patterns and workshops, in J. Coales (ed.) The Earliest English Brasses: Patronage, Style and Workshops 1270-1350, 133-74, London: Monumental Brass Society

BROWN, F. AND HOWARD-DAVIS, C. 2008. Norton Priory: Monastery to Museum, Lancaster Imprints, 16, Lancaster: Oxford Archaeology North 
BURTON, J. AND STÖBER, K. 2015. Abbeys and Priories of Medieval Wales, Cardiff: University of Wales Press

BUTLER, L. A. S. 1993. Cistercian abbots' tombs and seals, in M. P. Lillich (eds) Studies in Cistercian Art and Architecture, Cistercian Studies Series, 134, 78-88, Kalamazoo, MI: Cistercian Publications

BUTLER, L.A.S. 1976. Valle Crucis Abbey: an excavation in 1970, Archaeol. Camb., CXXV, $80-126$

CARTER, M. 2012. 'hys ... days here liven was' The monument of Abbot Robert Chamber at Holm Cultram (Cumbria), Church Monuments, XXVII, 38-52

COPPACK, G., FAWCETT, R. AND ROBINSON, D. 1999. A gazetteer of the Cistercian abbeys in Britain, in D. Robinson (ed.) The Cistercian Abbeys of Britain: Far from the Concourse of Men, 63-205, London: Batsford

COWLEY, F. G. 2005. Gilbert de Clare, earl of Gloucester (the Red Earl) and the Cistercians of south-east Wales, Archaeol. Cambrensis, 153, 115-24

EVANS, D. H. 2008. Valle Crucis Abbey. Pillar of Eliseg (revised edition). Cardiff: Cadw

GAJEWSKI, A. 2005. Burial, cult, and construction at the abbey church of Clairvaux (Clairvaix III), in J. Hall And C. Kratzke (eds) Sepultrae Cistercienses: Burial, Memorial and Patronage in Medieval Cistercian Monasteries, Revue D'Historie Cistercienne, 56, 47-85, Forges-Chimay, Belgium: Cîteaux: Commentarii cistercienses

GILCHRIST, R. AND SLOANE, B. 2005. Requiem: the Medieval Monastic Cemetery in Britain, London: Museum of London Archaeology Service

GILES, K. 2007. Seeing and believing: visuality and space in pre-modern England, World Archaeol., 39(1), 105-21

GITTOS, B AND GITTOS, M. 2002. The Ingleby Arncliffe group of effigies: a mid-fourteenth century workshop in North Yorkshire, Church Monuments, XVII, 14-38

GITTOS, B. AND GITTOS, M. 2012. Gresham revisited: a fresh look at the medieval monuments of north Wales, Archaeol. Camb., 161, 357-88

GRAVES, P. 2007. Sensing and believing: exploring worlds of difference in pre-modern England: a contribution to the debate opened by Kate Giles, World Archaeol., 39(4), 515-31

GRAY, M. 2005. Preface to Cisetercians in Wales and the West, Archaeol. Camb., 154, 27-50 
GREENHILL, F. A. 1976. Incised Effigial Slabs: A Study of Engraved Stone Memorials in Latin Christendom, c. 1100 to c. 1700, London: Faber and Faber

GRESHAM, C. 1968. Medieval Stone Carving in North Wales: Sepulchral Slabs and Effigies of the Thirteenth and Fourteenth Centuries, Cardiff: University of Wales Press

JAMROZIAK, E. 2005. Making friends beyond the grave: Melrose Abbey and its lay burials in the thirteenth century, in J. Hall and C. Kratzke (eds) Sepultrae Cistercienses: Burial, Memorial and Patronage in Medieval Cistercian Monasteries, Revue D'Historie Cistercienne, 56, 323-36, Forges-Chimay, Belgium: Cîteaux: Commentarii cistercienses

KRATZKE, C. 2005. SEPULKRALDENKMÄLER MECLENBURG-VORPOMMERN, In J. Hall and C. Kratzke (eds) Sepultrae Cistercienses: Burial, Memorial and Patronage in Medieval Cistercian Monasteries, Revue D'Historie Cistercienne, 56, 259-322, Forges-Chimay, Belgium: Cîteaux: Commentarii cistercienses

LEWIS, J. M. 1974. Welsh Monumental Brasses, Cardiff: National Museum of Wales MARKS, R. 2004. Image and Devotion in Late Medieval England, Stroud: Sutton NORRIS, M. 1977. Monumental Brasses: The Memorials, 2 volumes, London: Phillips and Page

PALMER, A. N. 1889. Notice of the discovery of sepulchral slabs at Valle Crucis Abbey, Denbighshire, Archaeol. Camb., Fifth Series, VI, XXI, 63-67

PENSON, R. K. 1851a. Excavations at Valle Crucis, Archaeol. Camb., VIII, 282

PENSON, R. K. 1851b. Evening meeting, Archaeol. Camb., VIII, 328-31

PRITCHARD, T. W. 1982. The Wynns at Wynnstay, Brookings, Or.: Old Court Press

PRYCE, H. 2005. Patrons and patronage among the Cistercians in Wales, Archaeol. Cambrensis, 154, 81-95

ROBERTS, A. 1876. Wynnstay and the Wynns. A Volume of Varieties, Oswestry: Woodall and Venables

ROGERS, N. 1987. ENGLISH EPISCOPAL MONUMENTS, 1270-1350, in J. Coales (ed.) The Earliest English Brasses: Patronage, Style and Workshops 1270-1350, 8-68, London: Monumental Brass Society

SARGENT, A. 2008. A re-used twelfth-century grave cover from St Andrew's, Cherry Hinton, Cambridge, Church Monuments, XXIII, 7-13 
SAUL, N. 2009. English Church Monuments in the Middle Ages: History and Representation, Oxford: Oxford University Press

SILLENCE, M. J. 2005. The two effigies of Archbishop Walter de Gray (d. 1255) at York Minster, Church Monuments, XX, 5-30

SMITH, D. AND LONDON, V. (eds) 2001. The Heads of Religious Houses England and Wales, II, 1216-1377, Cambridge: Cambridge University Press

STOCK, A. 2005. Grabdenkmäler aus Zisterzienserklöstern in Mitteldeutschland, in J. Hall and C. Kratzke (eds) Sepultrae Cistercienses: Burial, Memorial and Patronage in Medieval Cistercian Monasteries, Revue D'Historie Cistercienne, 56, 231-58, Forges-Chimay, Belgium: Cîteaux: Commentarii cistercienses

THOMAS, J. R. AND SOUTHERN, D. W. 2013. The Industrial Tramways of the Vale of Llangollen, Oakwood Press

WILLIAMS, D. 2001. The Welsh Cistercians, Leominster: Gracewing

WILLIAMS, D. 2014. Fasti Cisetercienses Cambrenses, Archaeol. Camb., 163, 185-235

WILLIAMS, H. 2003. Remembering and forgetting the medieval dead, in H. Williams (ed.) Archaeologies of Remembrance. Death and Memory in Past Societies, 227-54, New York: Kluwer/Plenum

WILLIAMS, S. 1895. Notes upon some sepulchral slabs and monumental effigies in Wales, Archaeol. Camb., XII No. XLVI, 112-33

WILLMOTT, H. AND TOWNEND, P. 2017. Richard De Wispeton. A face-to-face encounter with a medieval Lincolnshire priest, Current Archaeol., 326, 43-46 